LBNL-4941 1

\title{
Effect of Catalyst Structure on Oxidative Dehydrogenation of Ethane and Propane on Alumina-Supported Vanadia
}

\author{
Morris D. Argyle, Kaidong Chen, Alexis T. Bell*, and Enrique Iglesia* \\ Chemical and Material Sciences Divisions \\ Lawrence Berkeley National Laboratory \\ and \\ Department of Chemical Engineering \\ University of California \\ Berkeley, CA 94720-1462
}

\author{
Submitted to \\ Journal of Catalysis \\ January 28, 2002
}

*Authors to whom correspondence should be addressed [iglesia@cchem.berkeley.edu;
bell@cchem.berkeley.edu] 


\begin{abstract}
The catalytic properties of $\mathrm{Al}_{2} \mathrm{O}_{3}$-supported vanadia with a wide range of $\mathrm{VO}_{\mathrm{x}}$ surface density (1.4-34.2 V/nm ${ }^{2}$ ) and structure were examined for the oxidative dehydrogenation of ethane and propane. UV-visible and Raman spectra showed that vanadia is dispersed predominately as isolated monovanadate species below $\sim 2.3 \mathrm{~V} / \mathrm{nm}^{2}$. As surface densities increase, two-dimensional polyvanadates appear $\left(2.3-7.0 \mathrm{~V} / \mathrm{nm}^{2}\right)$ along with increasing amounts of $\mathrm{V}_{2} \mathrm{O}_{5}$ crystallites at surface densities above $7.0 \mathrm{~V} / \mathrm{nm}^{2}$. The rate constant for oxidative dehydrogenation $\left(\mathrm{k}_{1}\right)$ and its ratio with alkane and alkene combustion $\left(\mathrm{k}_{2} / \mathrm{k}_{1}\right.$ and $\mathrm{k}_{3} / \mathrm{k}_{1}$, respectively) were compared for both alkane reactants as a function of vanadia surface density. Propene formation rates (per $\mathrm{V}$-atom) are $\sim 8$ times higher than ethene formation rates at a given reaction temperature, but the apparent ODH activation energies $\left(E_{1}\right)$ are similar for the two reactants and relatively insensitive to vanadia surface density. Ethene and propene formation rates (per V-atom) are strongly influenced by vanadia surface density and reach a maximum value at intermediate surface densities $\left(\sim 8 \mathrm{~V} / \mathrm{nm}^{2}\right)$. The ratio of $\mathrm{k}_{2} / \mathrm{k}_{1}$ depends weakly on reaction temperature, indicating that activation energies for alkane combustion and ODH reactions are similar. The ratio of $\mathrm{k}_{2} / \mathrm{k}_{1}$ is independent of surface density for ethane, but increase slightly with vanadia surface density for propane, suggesting that isolated structures prevalent at low surface densities are slightly more selective for alkane dehydrogenation reactions. The ratio of $\mathrm{k}_{3} / \mathrm{k}_{1}$ decreases markedly with increasing reaction temperature for both ethane and propane $\mathrm{ODH}$. Thus, the apparent activation energy for alkene combustion $\left(\mathrm{E}_{3}\right)$ is much lower than that for alkane dehydrogenation $\left(E_{1}\right)$ and the difference between these two activation energies decreases with increasing surface density. The lower alkene selectivities observed at high vanadia surface densities are attributed to an increase in alkene adsorption enthalpies with increasing vanadia surface density. The highest yield of alkene is obtained for catalysts containing predominantly isolated monovanadate species and operated at high temperatures that avoid homogeneous reactions $(<\sim 800 \mathrm{~K})$.
\end{abstract}




\section{INTRODUCTION}

Low molecular weight alkenes, such as ethene and propene, can be formed via non-oxidative dehydrogenation of the corresponding alkane. Non-oxidative dehydrogenation reactions are endothermic and lead to the concurrent formation of carbon and of lower molecular weight alkanes, both of which decrease alkene yields. Oxidative dehydrogenation $(\mathrm{ODH})$ of light alkanes offers a potentially attractive route to alkenes, since the reaction is exothermic and avoids the thermodynamic constraints of non-oxidative routes by forming water as a byproduct. In addition, carbon deposition during ODH is eliminated, leading to stable catalytic activity. However, the yield of alkenes obtained by $\mathrm{ODH}$ on most catalysts is limited by alkene combustion to $\mathrm{CO}$ and $\mathrm{CO}_{2}\left(\mathrm{CO}_{\mathrm{x}}\right)$.

Previous studies have shown that supported vanadia is the most active and selective simple metal oxide for alkane $\mathrm{ODH}$, because its reducible nature leads to rapid redox cycles required for a catalytic turnover (1-5). Other studies (6-18) have probed the kinetics and selectivity of ethane and propane $\mathrm{ODH}$ on $\mathrm{VO}_{\mathrm{x}} / \mathrm{Al}_{2} \mathrm{O}_{3}$ and on $\mathrm{VO}_{\mathrm{x}}$ species supported on other metal oxides. These studies have shown that ODH rates per gram of catalyst and alkene selectivities are higher on dispersed $\mathrm{VO}_{\mathrm{x}}$ than on $\mathrm{V}_{2} \mathrm{O}_{5}$. The local structure of supported $\mathrm{VO}_{\mathrm{x}}$ domains strongly influence $\mathrm{ODH}$ reaction rates and selectivity (12-14). The effects of oxide domain size and of support on rates and selectivity have been attributed to the acid-base properties of the $\mathrm{VO}_{\mathrm{x}}$ and support surfaces $(1-5,7-18)$.

Alkane ODH reactions proceed via the reaction network shown in Scheme 1 (4, $10,12-14,19,20)$, in which alkanes react with lattice oxygen to form alkenes, with a rate 
constant $\mathrm{k}_{1}$, or $\mathrm{CO}_{\mathrm{x}}$, with a rate constant $\mathrm{k}_{2}$. The alkenes formed undergo subsequent oxidation to $\mathrm{CO}_{\mathrm{x}}$ with a rate constant $\mathrm{k}_{3}$. Reaction rates are nearly zero order in $\mathrm{O}_{2}$ and show a weak inhibition by $\mathrm{H}_{2} \mathrm{O}$ formed in $\mathrm{ODH}$ reactions $(14,21)$. A pseudo-first order kinetic analysis of Scheme 1 is sufficiently accurate to provide all three rate constants from rate and selectivity data as a function of reactor residence time. High alkene yields at reasonable residence times require high values of $k_{1}$ and low values of $k_{2} / k_{1}$ and $k_{3} / k_{1}$.

The effects of $\mathrm{VO}_{\mathrm{x}}$ surface density and structure on rates and selectivities for ethane and propane ODH reactions have been previously reported (7-18), with somewhat inconsistent results. For example, for ethane $\mathrm{ODH}$ on $\mathrm{VO}_{\mathrm{x}} / \gamma-\mathrm{Al}_{2} \mathrm{O}_{3}$ catalysts, the vanadia surface density that produces the highest ethane and ethene rates per $\mathrm{V}$ has been variously reported to occur at $\sim 33 \%$ (9), $\sim 50 \%$ (7), or $\sim 70 \%$ (2) of the polyvanadate monolayer coverage. As another example, the variation of propene selectivity with vanadia surface density has been reported to be insignificant over a range of $1.7-3.9 \mathrm{~V} / \mathrm{nm}^{2}(2,17)$ or quite significant, varying by $\sim 20 \%$, over this same range of vanadia surface densities (13) for propane $\mathrm{ODH}$ on $\mathrm{VO}_{\mathrm{x}} / \gamma-\mathrm{Al}_{2} \mathrm{O}_{3}$ catalysts. The lack of detailed structural characterization and of rigorous kinetic analysis of integral (high conversion) rate and selectivity data and the temperature gradients and possible homogeneous reactions prevalent at the high temperatures and conversions of many previous studies have contributed to the persistent controversies.

Here, we report a detailed kinetic analysis of ethane ODH reactions on $\mathrm{VO}_{\mathrm{x}} / \mathrm{Al}_{2} \mathrm{O}_{3}$ samples with a wide range of $\mathrm{VO}_{\mathrm{x}}$ surface densities $\left(1.4-34 \mathrm{VO}_{\mathrm{x}} / \mathrm{nm}^{2}\right)$ and contrast the results with those obtained using propane as the reactant. We have combined this analysis with detailed structural characterization of these catalysts in order to relate their 
local structure to the values of the rate constants, which characterize the function of these catalytic materials. In addition, we contrast the reaction rates of ethane and propane molecules with different $\mathrm{C}-\mathrm{H}$ bond energies and different adsorption energies of the respective alkenes.

\section{EXPERIMENTAL METHODS}

$\mathrm{VO}_{\mathrm{x}} / \mathrm{Al}_{2} \mathrm{O}_{3}$ catalysts were prepared by incipient wetness impregnation of fumed $\gamma$ alumina (Degussa, AG, $100 \mathrm{~m}^{2} / \mathrm{g}$ ) with an aqueous solution of ammonium metavanadate (99\%, Aldrich, Inc.) and oxalic acid (Mallinckrodt analytical grade) in a 1:2 weight ratio (12) with a $\mathrm{pH}$ of $\sim 2$. The impregnated samples were dried in air at $398 \mathrm{~K}$ for $\sim 16 \mathrm{~h}$, crushed, treated in $1.67 \mathrm{~cm}^{3} \mathrm{~s}^{-1}$ (STP) dry air (Airgas zero grade) at $773 \mathrm{~K}$ for $3 \mathrm{~h}$, and sieved to retain particles with $180-355 \mu$ m diameter.

Surface areas were measured by $\mathrm{N}_{2}$ physisorption (Airgas, $99.999 \%$ ) at its normal boiling point using a Quantasorb surface area analyzer and standard multi-point BET analysis methods. The catalyst samples were treated in flowing He (Airgas, 99.999\%) at $393 \mathrm{~K}$ for $2 \mathrm{~h}$ before $\mathrm{N}_{2}$ physisorption measurements.

Diffuse reflectance UV-visible spectra were measured with a Varian-Cary 4 spectrophotometer equipped with a Harrick diffuse-reflectance attachment. Samples were dehydrated in $20 \% \mathrm{O}_{2} / \mathrm{He}\left(1.67 \mathrm{~cm}^{3} \mathrm{~s}^{-1}\right.$ (STP), Praxair, 99.99\%) at $723 \mathrm{~K}$ before measuring spectra at ambient temperature between 1 and $5 \mathrm{eV}$. The Kubelka-Munk function $\left(\mathrm{F}\left(\mathrm{R}_{\infty}\right)\right)$ was used to convert diffuse reflectance data into absorption spectra using $\mathrm{MgO}$ as a standard (22). The absorption edge energy was estimated from $\mathrm{x}$ intercept of a linear fit in the near-edge region in a plot of $\left(\mathrm{F}\left(\mathrm{R}_{\infty}\right) h v\right)^{1 / 2}$ as a function of $h v$ (22). 
Raman spectra were obtained using a Hololab Series 5000 Raman spectrometer (Kaiser Optical) with a frequency-doubled $75 \mathrm{~mW}$ Nd-YAG laser at a wavelength of 532 nm. $\mathrm{VO}_{\mathrm{x}} / \mathrm{Al}_{2} \mathrm{O}_{3}$ samples $(\sim 0.05 \mathrm{~g})$ were pressed into wafers $(0.9 \mathrm{~cm}$ diameter, $\sim 0.1 \mathrm{~cm}$ thickness) at $40 \mathrm{MPa}$ and Raman spectra were measured at ambient temperatures before and after dehydration treatments. Dehydration was carried out at $723 \mathrm{~K}$ in flowing $20 \%$ $\mathrm{O}_{2}$ (Airgas 99.99\%) in He (Scott Specialty Gases, Inc. 99.9999\%) at a total flow rate of $1.0 \mathrm{~cm}^{3} \mathrm{~s}^{-1}$ (STP) for $0.75 \mathrm{~h}$. A rotating Raman cell $(20 \mathrm{~Hz})$ was used to prevent laser heating of the samples (23).

Reaction rate and selectivity data were measured in a packed bed flow reactor with plug-flow hydrodynamics (24). $\mathrm{VO}_{\mathrm{x}} / \mathrm{Al}_{2} \mathrm{O}_{3}$ catalysts $(0.01-0.3 \mathrm{~g})$ were diluted with quartz granules (180-355 $\mu \mathrm{m}$ diameter, 0.01-0.3 g) in order to prevent bed temperature gradients. Reaction measurements with $\mathrm{Al}_{2} \mathrm{O}_{3}$, quartz chips, or empty reactors did not lead to detectable products in the temperature range of the study. Typical propane and $\mathrm{O}_{2}$ conversion ranges on $\mathrm{VO}_{\mathrm{x}} / \mathrm{Al}_{2} \mathrm{O}_{3}$ catalysts were $1-2 \%$ and $10-20 \%$, respectively. A Hewlett-Packard 6890 gas chromatograph equipped with packed (Supelco Carboxen 1004) and capillary (HP-1, $50 \mathrm{~m}, 320 \mu \mathrm{m})$ columns and thermal conductivity and flame ionization detectors were used to measure the concentrations of reactants and products in the effluent stream.

Ethane ODH reactions were examined at $663-743 \mathrm{~K}$, while the faster propane ODH reactions were examined at lower temperatures (603-663 K). No homogeneous ethane or propane reactions were detected below $800 \mathrm{~K}$. Reactor residence times were adjusted by varying reactant flow rates between 0.083 and $4.2 \mathrm{~cm}^{3} \mathrm{~s}^{-1}$ (STP). Reactant mixtures consisted of ethane (14 kPa, Scott Specialty Gases, Inc., 99.999\%) or propane 
(14 kPa, Airgas, 99.9\%) with $\mathrm{O}_{2}(1.7 \mathrm{kPa}$, Praxair, 99.999\%) and $\mathrm{He}$ as an inert diluent (Airgas, 99.9999\%).

Conversion and selectivity were calculated from the measured GC compositions. These data were used to calculate reaction rates from the reactant and product molar flow rates. The reaction rates and selectivities as a function of residence time were used to obtain initial alkane dehydrogenation and combustion reaction rates and the rate constants in Scheme 1. The sequence in Scheme 1 can be used to obtain the $\mathrm{k}_{1}$ and $\mathrm{k}_{2}$ rate constants from the initial alkene selectivity:

$$
\mathrm{S}_{\mathrm{CxH} 2 \mathrm{x}}^{0}=\mathrm{k}_{1} /\left(\mathrm{k}_{1}+\mathrm{k}_{2}\right)
$$

and $\mathrm{k}_{3}$ from the observed changes in alkene selectivity with residence time

$$
\begin{aligned}
\mathrm{S}_{\mathrm{CxH} 2 \mathrm{x}} & =\mathrm{S}_{\mathrm{CxH2x}}^{0}\left[1-\left(\mathrm{k}_{1}+\mathrm{k}_{2}+\mathrm{k}_{3}\right) \mathrm{C}_{\mathrm{V}} \tau / 2\right] \\
& \tau, \text { residence time } \\
& \mathrm{C}_{\mathrm{V}} \text {, concentration of } \mathrm{V} \text { atoms per reactor volume }
\end{aligned}
$$

as described in detail elsewhere (12).

\section{RESULTS AND DISCUSSION}

\section{Catalyst Characterization}

BET surface areas and apparent $\mathrm{VO}_{\mathrm{x}}$ surface densities, estimated from the $\mathrm{V}$ content and the BET surface areas, are shown in Table 1 for all $\mathrm{VO}_{\mathrm{x}} / \mathrm{Al}_{2} \mathrm{O}_{3}$ samples. Surface areas (per g-sample) decrease with increasing $\mathrm{VO}_{\mathrm{x}}$ content. This trend corresponds to the low surface area of the added $\mathrm{VO}_{\mathrm{x}}$ because the surface area normalized per alumina content, listed in the last column of Table 1, is approximately constant. However, the $30 \mathrm{wt} \%$ sample shows a decrease in surface area per gram of 
alumina, suggesting that the formation of larger $\mathrm{V}_{2} \mathrm{O}_{5}$ crystallites blocks some support pores.

The UV-visible spectra and the absorption edge energies for all $\mathrm{VO}_{\mathrm{x}} / \mathrm{Al}_{2} \mathrm{O}_{3}$ samples are shown in Figures 1a and 1b, respectively. $\mathrm{VO}_{\mathrm{x}} / \mathrm{Al}_{2} \mathrm{O}_{3}$ samples with 8.0, 12.5, 16.6 , and $34.2 \mathrm{~V} / \mathrm{m}^{2}$ exhibit two linear regions in the near-edge region, indicating the presence of two distinct $\mathrm{VO}_{\mathrm{x}}$ structures. For those samples, two edge energies are measured and both are included in Figure 1b. The low-energy absorption edge decreases in energy with increasing surface density, approaching values typical of bulk $\mathrm{V}_{2} \mathrm{O}_{5}(2 \mathrm{eV})$ (25). The edge energies based on the second linear portion of the near edge region are higher than those based on the first linear portion and appear to be independent of the vanadia surface density. Absorption edge energies above $2.5 \mathrm{eV}$ are attributable to $\mathrm{V}^{5+}$ in distorted tetrahedral coordination (25). Thus, UV-visible spectroscopy suggests that $\mathrm{V}^{5+}$ is present in distorted tetrahedrally coordinated species at low vanadia surface densities and that some of these tetrahedrally coordinated cations remain at higher surface densities, coexisting with an increasing fraction of $\mathrm{V}^{5+}$ present in distorted tetragonal pyramidal coordination, similar to that present in $\mathrm{V}_{2} \mathrm{O}_{5}(25)$.

Raman spectra, obtained at ambient temperature after treatment at $723 \mathrm{~K}$ in $20 \%$ $\mathrm{O}_{2} / \mathrm{He}$, for the $\mathrm{VO}_{\mathrm{x}} / \mathrm{Al}_{2} \mathrm{O}_{3}$ samples are shown in Figure 2. $\mathrm{V}=\mathrm{O}$ stretches in isolated tetrahedral monovanadates appear at $1033 \mathrm{~cm}^{-1}$, while $\mathrm{V}-\mathrm{O}-\mathrm{V}$ stretches in twodimensional polyvanadates have been proposed to lead to broad Raman features at 750$1000 \mathrm{~cm}^{-1}(25-27)$. The remaining bands, appearing at 998, 706, 530, 489, 410, 305, 289, 203, and $150 \mathrm{~cm}^{-1}$ correspond to bulk $\mathrm{V}_{2} \mathrm{O}_{5}$ crystals $(1,25)$. The $\mathrm{V}_{2} \mathrm{O}_{5}$ bands in some of these spectra are intense, but the Raman cross section for $\mathrm{V}_{2} \mathrm{O}_{5}$ crystals is about ten times 
larger than for monovanadate species (23). Using this value, the ratio of V-atoms in $\mathrm{V}_{2} \mathrm{O}_{5}$ to those in monovanadate increase from 0 to 2.5 as $\mathrm{VO}_{\mathrm{x}}$ surface densities increase from 1.4 to $34.2 \mathrm{~V} / \mathrm{nm}^{2}$. Geometric calculations, assuming flat, ordered support surfaces predict that a theoretical monolayer of monovanadate species occurs at $2.3 \mathrm{~V} / \mathrm{nm}^{2}$, and at $7.0 \mathrm{~V} / \mathrm{nm}^{2}$ if polyvanadate species are present $(12,28)$. Over this range of $\mathrm{VO}_{\mathrm{x}}$ surface densities, the ratio of $\mathrm{V}_{2} \mathrm{O}_{5}$ to monovanadate species increases from $\sim 0.02$ to $\sim 0.1$. Thus, under either definition of a monolayer, most of the surface is covered by vanadate species other than $\mathrm{V}_{2} \mathrm{O}_{5}$. Specifically, the $\mathrm{V}_{2} \mathrm{O}_{5}$ :monovandate ratio increases from 0.085 for the catalyst with a vanadia surface density of $3.6 \mathrm{~V} / \mathrm{nm}^{2}$ to 0.115 for the catalyst with a vanadia surface density of $8.0 \mathrm{~V} / \mathrm{nm}^{2}$. This represents an increase of $35 \%$ in the ratio of $\mathrm{V}_{2} \mathrm{O}_{5}$ to monovanadate species at the same time that the vanadia concentration doubled, indicating that the additional vanadia formed structures that are neither isolated monovanadates nor $\mathrm{V}_{2} \mathrm{O}_{5}$ crystallites. The $\mathrm{V}_{2} \mathrm{O}_{5}$ :monovandate ratio increases to 0.63 , 1.3 , and 2.5 for the catalysts with vanadia surface densities of $12.5,16.6$, and $32.4 \mathrm{~V} / \mathrm{nm}^{2}$, which have vanadia concentrations of 15,20 , and $30 \mathrm{wt} \%$, respectively. The increase in $\mathrm{V}_{2} \mathrm{O}_{5}$ :monovadate ratio is proportionally larger than the additional vanadia content of these catalysts, suggesting that all added vanadia forms $\mathrm{V}_{2} \mathrm{O}_{5}$ structures while simultaneously incorporating some monovanadates.

The spectroscopic results presented in Figures 1 and 2 suggest that distorted tetrahedral monovanadate structures connected to the support via $\mathrm{V}-\mathrm{O}-\mathrm{Al}$ bonds are prevalent at low surface densities. As $\mathrm{V}$ surface densities increase, two-dimensional polyvanadates form via reactions leading to $\mathrm{V}-\mathrm{O}-\mathrm{V}$ bonds connecting neighboring $\mathrm{VO}_{\mathrm{x}}$ species. $\mathrm{VO}_{\mathrm{x}}$ species exceeding monolayer coverages react with polyvanadates structures 
to form three-dimensional structures that ultimately crystallize into bulk $\mathrm{V}_{2} \mathrm{O}_{5}$, with some evidence for residual monovanadate species.

\section{Oxidative Dehydrogenation Rates and Selectivity}

$\mathrm{C}_{2} \mathrm{H}_{4}, \mathrm{CO}$, and $\mathrm{CO}_{2}$ formation rates and $\mathrm{C}_{2} \mathrm{H}_{6}$ conversion level and $\mathrm{C}_{2} \mathrm{H}_{4}, \mathrm{CO}$, and $\mathrm{CO}_{2}$ selectivities are shown as a function of nominal reactor residence time in Figures $3 \mathrm{a}$ and $3 \mathrm{~b}$ for the $8.0 \mathrm{~V} / \mathrm{nm}^{2}$ sample. The lines shown were used to extrapolate rates and selectivity to zero reactor residence time or reactant conversion and to estimate the rates of secondary oxidation of $\mathrm{C}_{2} \mathrm{H}_{4}$. The decrease in $\mathrm{C}_{2} \mathrm{H}_{6}$ conversion rates with increasing residence time (Fig. 3a) reflects a slight inhibition of ethane dehydrogenation rates by the water formed during reaction (21), as reported previously for propane reactions $(14,29$, 30). The decrease in ethene selectivity with increasing residence time (Fig. 3b) arises from secondary ethene oxidation reactions (Scheme 1). Data acquisition methods similar to those described for ethane $\mathrm{ODH}$ were used to obtain the propane ODH data. The conversion and selectivity trends displayed in Figure 3 for ethane ODH are similar to those observed for propane ODH, as described in more detail elsewhere $(13,14)$.

Figures $4 \mathrm{a}$ and $4 \mathrm{~b}$ show the effect of vanadia surface density on the initial rate of alkene formation per $\mathrm{V}$ atom (extrapolated to zero residence time). For both ethane and propane reactants, these apparent turnover rates reach a maximum at intermediate vanadia surface densities. The maximum rate is reached at a surface $\mathrm{VO}_{\mathrm{x}}$ density of $\sim 8$ $\mathrm{V} / \mathrm{nm}^{2}$ for both reactants, and this maximum rate is about four times greater than that obtained on the $\mathrm{VO}_{\mathrm{x}} / \mathrm{Al}_{2} \mathrm{O}_{3}$ sample with the lowest surface density $\left(1.4 \mathrm{~V} / \mathrm{nm}^{2}\right)$. Welldispersed monovanadate species prevalent in the latter sample are significantly less active than oligomeric $\mathrm{VO}_{\mathrm{x}}$ structures that appear as the vanadia surface density increases. The 
rate per $\mathrm{V}$-atom increases with surface densities, even though $\mathrm{V}$-atoms become increasingly unavailable for catalysis as three-dimensional structures form. Thus, the surface reactivity of $\mathrm{VO}_{\mathrm{x}}$ increases even more markedly with surface density than suggested by the data in Figure 4. For a given $\mathrm{VO}_{\mathrm{x}}$ surface density, the apparent turnover rates for propane reactants is $\sim 8$ times higher than for ethane, but the effects of vanadia surface density and the higher surface reactivity of the $\mathrm{VO}_{\mathrm{x}}$ oligomers are observed for both alkane reactants.

Figures $4 \mathrm{a}$ and $4 \mathrm{~b}$ show that apparent turnover rates for both ethane and propane decrease at $\mathrm{VO}_{\mathrm{x}}$ surface densities above $\sim 8 \mathrm{~V} / \mathrm{nm}^{2}$, as also found previously for propane ODH on $\mathrm{VO}_{\mathrm{x}} / \mathrm{ZrO}_{2}$ (31). These trends reflect the introduction of additional vanadia species within the inaccessible bulk of three-dimensional structures. The picture of the sample surfaces evolving from isolated and sparsely distributed monovanadates, to nearly complete polyvanadate monolayers, followed by the gradual building of additional layers would lead to low areal ODH rates at low surface densities, because most of the surface area is inactive $\mathrm{Al}_{2} \mathrm{O}_{3}$. The increasing coverage of the $\mathrm{Al}_{2} \mathrm{O}_{3}$ with monovanadate and with more reactive polyvanadates would increase the measured areal rates, until the entire surface is covered with $\mathrm{VO}_{\mathrm{x}}$ species. If the surface reactivity of such species becomes independent of the presence and scale of the third dimension, the areal rates would reach a constant value. These trends are confirmed by the areal rates of alkene formation from ethane or propane, plotted as a function of vanadia surface density in Figures 5a and $5 \mathrm{~b}$. These areal rates increase with increasing surface density and approach nearly constant values for vanadia surface densities higher than $10 \mathrm{~V} / \mathrm{nm}^{2}$, as also found for propane ODH on $\mathrm{VO}_{\mathrm{x}} / \mathrm{ZrO}_{2}$ (31). The constant areal rate obtained after completion of a 
polyvanadate monolayer suggests that the surface reactivity of $\mathrm{VO}_{\mathrm{x}}$ species becomes independent of domain size once the predominant structures involve $\mathrm{V}-\mathrm{O}-\mathrm{V}$ bonds.

Figure 6 shows activation energies $\left(E_{1}\right)$ obtained from Arrhenius plots for ethene and propene formation rates from the corresponding alkanes as a function of $\mathrm{VO}_{\mathrm{x}}$ surface density. Ethane and propane dehydrogenation show similar activation energies, and the value decreases slightly for both reactants with increasing $\mathrm{VO}_{\mathrm{x}}$ surface density. Similar and even lower values of $E_{1}$ than those presented in Figure 6 have been reported for ethane $\mathrm{ODH}$ on $\mathrm{VO}_{\mathrm{x}} / \mathrm{Al}_{2} \mathrm{O}_{3}$ (7). The similar values of $\mathrm{E}_{1}$ of the two reactants is unexpected, because propane dehydrogenation is significantly faster than ethane dehydrogenation. Since $\mathrm{C}-\mathrm{H}$ bond activation is the kinetically relevant step in dehydrogenation of propane $(1-4,12,14,19,2930)$ and also ethane on vanadia-based catalysts (19), and the methylene $\mathrm{C}-\mathrm{H}$ bonds in propane are considerably weaker than the methyl C-H bonds in ethane ( $401 \mathrm{~kJ} / \mathrm{mol}$ vs. $420 \mathrm{~kJ} / \mathrm{mol}$ ), a lower activation energy is expected for propane than for ethane dehydrogenation reactions. Therefore, other factors must account for the equivalence of the activation energies for ethane and propane ODH. One of these factors may be the stability of the alkyl radical formed upon $\mathrm{C}-\mathrm{H}$ bond activation. A higher stabilization energy for ethoxide species relative to isopropoxide species could compensate for the differences in $\mathrm{C}-\mathrm{H}$ bond energies in the transition state involved in $\mathrm{C}-\mathrm{H}$ bond activation and lead to similar activation energies for the two alkane reactants.

Dehydrogenation rates are much lower for ethane than for propane (Figure 4) even though activation energies are similar (Figure 6). This means that either the number of active sites or the pre-exponential factor must be much lower for ethane than for 
propane reactants. It appears unlikely that the mechanism or site requirements would differ for two alkanes as similar as propane and ethane, which react via similar redox mechanisms using lattice oxygen atoms $(1-5,12,14,21,29,30)$. The lower preexponential factors would then have to reflect a larger negative entropy of formation of the transition state for ethane than for propane. An analysis based on transition state theory and on the expected structures of activated complexes required for $\mathrm{C}-\mathrm{H}$ bond activation, however, does not indicate that the activation entropy of ethane ODH is more negative than that of propane ODH. These theoretical considerations suggest that activation entropy differences do not explain the higher rate of propane ODH relative to ethane ODH.

Figure 7 illustrates the effect of $\mathrm{VO}_{\mathrm{x}}$ surface density on alkene selectivities. The initial selectivity to ethene is $\sim 75 \%$ for ethane $\mathrm{ODH}$ on $\mathrm{VO}_{\mathrm{x}} / \mathrm{Al}_{2} \mathrm{O}_{3}$ and it does not change significantly with increasing $\mathrm{VO}_{\mathrm{x}}$ surface density (Figure $7 \mathrm{a}$ ). $\mathrm{CO}$ is the major byproduct and only a small amount of $\mathrm{CO}_{2}$ is formed. For propane ODH reactions, initial propene selectivities are $\sim 85 \%$ at the lowest vanadia surface densities, but they decrease to values similar to those for ethane reactants with increasing surface density (Figure 7b).

The ratios of rate constants for alkane direct combustion and dehydrogenation $\left(\mathrm{k}_{2} / \mathrm{k}_{1}\right)$ are shown in Figure 8 as a function of $\mathrm{VO}_{\mathrm{x}}$ surface density. For ethane, $\mathrm{k}_{2} / \mathrm{k}_{1}$ is essentially independent of $\mathrm{VO}_{\mathrm{x}}$ surface density, but this ratio increases with increasing $\mathrm{VO}_{\mathrm{x}}$ surface density for propane reactants. For ethane, $\mathrm{k}_{2} / \mathrm{k}_{1}$ is weakly dependent on temperature, while for propane, $\mathrm{k}_{2} / \mathrm{k}_{1}$ is essentially independent of temperature on all samples, indicating that the activation energies for alkene and $\mathrm{CO}_{\mathrm{x}}$ formation directly from alkanes $\left(E_{1}\right.$ and $\left.E_{2}\right)$ are very similar (Figure 9). The differences between these two 
activation energies $\left(\Delta \mathrm{E}_{12}=\mathrm{E}_{1}-\mathrm{E}_{2}\right)$ are small, positive, and independent of $\mathrm{VO}_{\mathrm{x}}$ surface density for ethane, but change from positive to negative with increasing $\mathrm{VO}_{\mathrm{x}}$ surface density for propane $\mathrm{ODH}$. These trends are consistent with the observed trends in $\mathrm{k}_{2} / \mathrm{k}_{1}$ shown in Figure 8.

Figure 10 shows ratios of rate coefficients for alkene combustion and alkane dehydrogenation $\left(\mathrm{k}_{3} / \mathrm{k}_{1}\right)$. For both reactants, $\mathrm{k}_{3} / \mathrm{k}_{1}$ increases with increasing $\mathrm{VO}_{\mathrm{x}}$ surface density and decreases with increasing temperature on all samples. This is consistent with a lower activation energy for alkene reactions $\left(E_{3}\right)$ than for alkane reactions $\left(E_{1}\right)$. This activation energy differences $\left(\Delta \mathrm{E}_{13}=\mathrm{E}_{1}-\mathrm{E}_{3}\right)$ decreases for both alkanes with increasing $\mathrm{VO}_{\mathrm{x}}$ surface density (Figure 11), consistent with trends shown in Figure 10. $\mathrm{E}_{1}$ values decrease very slightly with increasing surface density; thus, the observed changes in $\Delta \mathrm{E}_{13}$ arise almost exclusively from an increase in the value of $\mathrm{E}_{3}$ with increasing $\mathrm{VO}_{\mathrm{x}}$ surface density.

Changes in alkene adsorption enthalpies may account for the observed increase in alkene combustion activation energies $\left(E_{3}\right)$ with increasing vanadia surface density. Theoretical estimates of enthalpies for ethene adsorption on supported polyvanadate monolayers $\left(\mathrm{V}_{2} \mathrm{O}_{5}(001) / \mathrm{TiO}_{2}(001)\right.$ (anatase)) and bulk $\mathrm{V}_{2} \mathrm{O}_{5}(001)$ surfaces (32) give values of $-79.6 \mathrm{~kJ} / \mathrm{mol}$ and $-39.7 \mathrm{~kJ} / \mathrm{mol}$, respectively. These density functional theory calculations are consistent with a higher activation energy on the bulk $\mathrm{V}_{2} \mathrm{O}_{5}$ surface, which binds ethene much more weakly than two-dimensional $\mathrm{VO}_{\mathrm{x}}$ structures. This is apparent from the definition of $\mathrm{k}_{3}$ as $\mathrm{K}_{3} \mathrm{k}_{3}{ }^{\text {act }}$, where $\mathrm{K}_{3}$ is the equilibrium constant for ethene adsorption and $\mathrm{k}_{3}^{\text {act }}$ is the rate constant for the activation of a $\mathrm{C}-\mathrm{H}$ bond in ethene. Thus, the apparent activation energy is given by $\Delta \mathrm{H}_{3}+\mathrm{E}_{3}^{\text {act }}$, where $\Delta \mathrm{H}_{3}$ is the 
ethene adsorption enthalpy and $\mathrm{E}_{3}{ }^{\text {act }}$ is activation energy for the kinetically relevant $\mathrm{C}-\mathrm{H}$ bond activation step in adsorbed ethene (29). The enthalpy of adsorption of ethane is not very sensitive to $\mathrm{VO}_{\mathrm{x}}$ surface structure $\left(-27.4 \mathrm{~kJ} / \mathrm{mol}\right.$ on $\mathrm{V}_{2} \mathrm{O}_{5}(001) / \mathrm{TiO}_{2}$ and -25.4 $\mathrm{kJ} / \mathrm{mol}$ on $\mathrm{V}_{2} \mathrm{O}_{5}(001)(32)$ ). Taken together with the nearly constant values of $\mathrm{E}_{1}$ (Figure 6) on $\mathrm{VO}_{\mathrm{x}} / \mathrm{Al}_{2} \mathrm{O}_{3}$ samples with a wide range of surface density, this suggests that the energy for $\mathrm{C}-\mathrm{H}$ bond activation in ethane $\left(\mathrm{E}_{1}{ }^{\text {act }}\right)$ is not influenced by vanadia surface density. The mechanistic and kinetic resemblance between $\mathrm{C}-\mathrm{H}$ bond activation steps in alkanes and alkenes and the different observed sensitivities of $E_{1}$ and $E_{3}$ on surface density, suggest that only the adsorption enthalpy of alkenes and not that of alkanes or the values of $\mathrm{C}-\mathrm{H}$ bond activation energies $\left(\mathrm{E}_{1}{ }^{\text {act }}, \mathrm{E}_{3}{ }^{\text {act }}\right)$ change with $\mathrm{VO}_{\mathrm{x}}$ surface density.

The sample with the lowest vanadia surface density $\left(1.4 \mathrm{~V} / \mathrm{nm}^{2}\right)$ and containing predominately monovanadates shows the highest initial alkene selectivity for both ethane and propane ODH. Increasing vanadia surface density either has no effect or decreases initial alkene selectivities. The ratio of $k_{2} / k_{1}$ is independent of surface density for ethane and increase with increasing vanadia surface density for propane (Figure 8). The ratio of $\mathrm{k}_{3} / \mathrm{k}_{1}$ increases with increasing vanadia surface density for both reactants (Figure 10). Smaller values of $\mathrm{k}_{3} / \mathrm{k}_{1}$ and $\mathrm{k}_{2} / \mathrm{k}_{1}$ lead to higher alkene selectivity at all reactant conversion levels. As a result, the $1.4 \mathrm{~V} / \mathrm{nm}^{2}$ catalyst is the most selective for both alkanes. However, the alkene formation rates (per V-atom) for the $1.4 \mathrm{~V} / \mathrm{nm}^{2}$ catalyst are $\sim 4$ times lower at a given reaction temperatures compared to the $8.0 \mathrm{~V} / \mathrm{nm}^{2}$ catalyst (Figure 4), but the rate difference can be overcome by increasing reaction temperatures. The ratio of $\mathrm{k}_{2} / \mathrm{k}_{1}$ is relatively independent of reaction temperature, and the value of $\mathrm{k}_{3} / \mathrm{k}_{1}$ actually decreases with increasing temperature for both reactants, leading to an increase 
in alkene selectivity with increasing reaction temperature. Therefore, the alkene yield can be maximized using a catalyst covered with dispersed monovanadate species, operated at high reaction temperature. The maximum operating temperature is determined by the onset of homogeneous reactions. 


\section{CONCLUSIONS}

The rate and selectivity of ethane and propane $\mathrm{ODH}$ on $\mathrm{VO}_{\mathrm{x}} / \mathrm{Al}_{2} \mathrm{O}_{3}$ catalysts depend on the vanadia surface densities and reaction temperature. Ethane ODH at zero conversion is $\sim 75 \%$ selective to ethene and insensitive to vanadia surface density, while initial propene selectivities during propane ODH approach $90 \%$ at low vanadia surface densities, but decrease with increasing vanadia surface density. The ratio of $k_{2} / k_{1}$ is relatively independent of both reaction temperature and vanadia surface density for ethane $\mathrm{ODH}$. The ratio of $\mathrm{k}_{2} / \mathrm{k}_{1}$ is independent of reaction temperature, but increases with increasing vanadia surface density for propane $\mathrm{ODH}$. However, $\mathrm{k}_{3} / \mathrm{k}_{1}$ is generally higher for propane than for ethane $\mathrm{ODH}$, indicating that the propene is more reactive relative to propane than ethene is to ethane. The activation energies for ethane and propane $\mathrm{ODH}, \mathrm{E}_{1}$, and ethane and propane combustion, $\mathrm{E}_{2}$, are similar in magnitude at $\sim 115 \pm 20 \mathrm{~kJ} / \mathrm{mol}$ and show weak dependence on vanadia surface density. The propene formation rate is $\sim 8$ times larger than the ethene formation rate at $663 \mathrm{~K}$, suggesting that that the stabilization energy for ethoxide species may be higher relative to isopropoxide in the activated state. The apparent activation energy for alkene combustion, $E_{3}$, is $\sim 60$ $90 \mathrm{~kJ} / \mathrm{mol}$ and increases with vanadia surface density, leading to a decrease in $\Delta \mathrm{E}_{13}$ with increasing vanadia surface density. The trends in $\mathrm{E}_{3}$ and $\Delta \mathrm{E}_{13}$ appear to be caused by decreasingly exothermic alkene adsorption as vanadia surface density increases. Alkene selectivity generally increases with increasing reaction temperature and with decreasing vanadia surface density. Therefore, the highest olefin yields are obtained on catalysts containing isolated monovanadates and operated at the highest possible reaction temperature consistent with the avoidance of homogeneous reactions. 


\section{ACKNOWLEDGMENTS}

This work was supported by the Director, Office of Basic Energy Sciences, Chemical Sciences Division of the U.S. Department of Energy under Contract DE-AC0376SF00098. 


\section{REFERENCES}

1. Kung, H. H., Advances in Catalysis 40, 1 (1994).

2. Mamedov, E. A., Cortés Corberán, V., Appl. Catal. A 127, 1 (1995).

3. Albonetti, S., Cavani, F., and Trifirò, F., Catal. Rev.-Sci. Eng. 38, 413 (1996).

4. Blasco, T. and López Nieto, J. M., Appl. Catal. A 157, 117 (1997).

5. Bañares, M. A., Catal. Today 51, 319 (1999).

6. Thorsteinson, E. M., Wilson, T. P., Young, F. G., and Kasai, P. H., J. Catal. 52, 116 (1978).

7. Le Bars, J., Auroux, A., Forissier, M., and Vedrine, J. C., J. Catal. 162, 250 (1996).

8. Le Bars, J., Vedrine, J. C., J. Auroux, A., Trautmann, S., Baerns, M., Appl. Catal. A 119, 341 (1994).

9. Bañares, M. A., Gao, X., Fierro, J. L. G, and Wachs, I. E., Stud. Surf. Sci. Catal. 110, 295-304 (1997).

10. Blasco, T., Galli, A., López Nieto, J. M., Trifiró, F., J. Catal. 169, 203 (1997).

11. Gao, X., Banares, M. A., and Wachs, I. E., J. Catal. 188, 325 (1999).

12. Khodakov, A., Yang, J., Su, S., Iglesia, E., and Bell, A. T., J. Catal. 177, 343 (1998).

13. Khodakov, A., Olthof, B., Bell, A. T., and Iglesia, E., J. Catal. 181, 205 (1999).

14. Chen, K.D., Khodakov, A., Yang, J., Bell, A. T., and Iglesia, E., J. Catal. 186, 325 (1999).

15. Arena, F., Frusteri, F., Parmaliana, A., Catal. Lett. 60, 59 (1999).

16. Corma, A, López-Nieto, J. M., Paredes, N, Pérez, M., Shen, Y., Cao, H., Suib, S. L., Stud. Surf. Sci. Catal. 72, 213 (1992). 
17. Eon, J. G., Olier, R., Volta, J. C., J. Catal. 145, 318 (1994).

18. Eon, J.-G., Pries de Oliveira, P. G., Lefebvre, F., Volta, J.-C., Stud. Surf. Sci. Catal. 82, 83 (1994).

19. Batiot, C. and Hodnett, B. K., Appl. Catal. A 137, 179 (1996).

20. Cassidy, F. E., Hodnett, B. K., CATTECH 2, 173 (1998).

21. Argyle, M. D., Chen, K. D., Bell, A. T., and Iglesia, E., submitted to J. Phys. Chem. $B$.

22. Barton, D. G., Shtein, M., Wilson, R. D., Soled, S. L., and Iglesia, E., J. Phys. Chem. B 103, 630 (1999).

23. Xie, S., Iglesia, E., and Bell, A. T., Langmuir 16, 7162 (2000).

24. Iglesia, E., Baumgartner, J. E., and Price, G. L., J. Catal. 134, 549 (1992).

25. Olthof, B., Khodakov, A., Bell, A. T. and Iglesia, E., J. Phys. Chem. B 104, 1516 (2000).

26. Wachs, I. E., Catal. Today 27, 437 (1996).

27. Vuurman, M. A., Wachs, I. E., J. Phys. Chem. 96, 5008 (1992).

28. Centi, G., Appl. Catal. A 147, 267 (1996).

29. Chen, K. D., Bell, A. T., Iglesia, E., J. Phys. Chem. B 104, 1292 (2000).

30. Chen, K. D., Xie, S., Iglesia, E. and Bell, A. T., J. Catal. 189, 421 (2000).

31. Chen, K. D., Iglesia, E. and Bell, A. T., unpublished results.

32. Sayle, D. C., Catlow, C. R. A., Perrin, M. A., Nortier, P., Catal. Lett. 38, 203 (1996). 


\section{Figure Captions:}

Figure 1. (a) Diffuse reflectance UV-visible spectra and (b) absorption edge energies for $\mathrm{VO}_{\mathrm{x}} / \mathrm{Al}_{2} \mathrm{O}_{3}$ catalysts

Figure 2. Raman spectra for $\mathrm{VO}_{\mathrm{x}} / \mathrm{Al}_{2} \mathrm{O}_{3}$ catalysts (obtained at $298 \mathrm{~K}$ in flowing dry $20 \%$ $\mathrm{O}_{2} / \mathrm{He}$ after treatment at $723 \mathrm{~K}$ for $0.75 \mathrm{~h}$ )

Figure 3. Example of ethane $\mathrm{ODH}$ (a) reaction rates and (b) selectivity and conversion as a function of reciprocal flow rate $\left(10 \% \mathrm{~V}_{2} \mathrm{O}_{5} / \mathrm{Al}_{2} \mathrm{O}_{3}, 723 \mathrm{~K}, 14 \mathrm{kPa} \mathrm{C}_{2} \mathrm{H}_{6}, 1.7 \mathrm{kPa} \mathrm{O}\right.$, balance $\mathrm{He}$ )

Figure 4. Initial alkene formation rates as a function of vanadia surface density on $\mathrm{VO}_{\mathrm{x}} / \mathrm{Al}_{2} \mathrm{O}_{3}$ catalysts: (a) ethane $\mathrm{ODH}$, (b) propane $\mathrm{ODH}\left(663 \mathrm{~K}, 14 \mathrm{kPa} \mathrm{C}_{2} \mathrm{H}_{6}\right.$ or $\mathrm{C}_{3} \mathrm{H}_{8}$, $1.7 \mathrm{kPa} \mathrm{O}_{2}$, balance $\mathrm{He}$ )

Figure 5. Initial alkene formation rates normalized per unit catalyst surface area as a function of vanadia surface density: (a) ethane $\mathrm{ODH}$, (b) propane $\mathrm{ODH}(663 \mathrm{~K}, 14 \mathrm{kPa}$ $\mathrm{C}_{2} \mathrm{H}_{6}$ or $\mathrm{C}_{3} \mathrm{H}_{8}, 1.7 \mathrm{kPa} \mathrm{O}$, balance $\mathrm{He}$ )

Figure 6. $\mathrm{ODH}$ reaction activation energy, $\mathrm{E}_{1}$, as a function of vanadia surface density on $\mathrm{VO}_{\mathrm{x}} / \mathrm{Al}_{2} \mathrm{O}_{3}$ catalysts: (a) ethane, (b) propane (14 $\mathrm{kPa}$ alkane, $1.7 \mathrm{kPa} \mathrm{O}$, balance $\mathrm{He}$ )

Figure 7. ODH selectivities as a function of vanadia surface density on $\mathrm{VO}_{\mathrm{x}} / \mathrm{Al}_{2} \mathrm{O}_{3}$ catalysts: (a) ethane, (b) propane; $\left(663 \mathrm{~K}, 14 \mathrm{kPa}\right.$ alkane, $1.7 \mathrm{kPa} \mathrm{O}_{2}$, balance $\left.\mathrm{He}\right)$

Figure 8. Rate constant ratio $\mathrm{k}_{2} / \mathrm{k}_{1}$ as a function of vanadia surface density on $\mathrm{VO}_{\mathrm{x}} / \mathrm{Al}_{2} \mathrm{O}_{3}$ catalysts: (a) ethane $\left(14 \mathrm{kPa} \mathrm{C}_{2} \mathrm{H}_{6}, 1.7 \mathrm{kPa} \mathrm{O}\right.$, balance $\left.\mathrm{He}\right)$, (b) propane (14 $\mathrm{kPa} \mathrm{C}_{3} \mathrm{H}_{8}, 1.7 \mathrm{kPa} \mathrm{O}$, balance $\mathrm{He}$ )

Figure 9. Difference between $\mathrm{ODH}$ activation energy and alkane combustion activation energy $\left(\Delta \mathrm{E}_{12}=\mathrm{E}_{1}-\mathrm{E}_{2}\right)$ on $\mathrm{VO}_{\mathrm{x}} / \mathrm{Al}_{2} \mathrm{O}_{3}$ catalysts: (a) ethane $\left(663 \mathrm{~K}, 14 \mathrm{kPa} \mathrm{C} \mathrm{H}_{6}, 1.7 \mathrm{kPa}\right.$ $\mathrm{O}_{2}$, balance $\left.\mathrm{He}\right),\left(\right.$ b) propane $\left(663 \mathrm{~K}, 14 \mathrm{kPa} \mathrm{C}_{3} \mathrm{H}_{8}, 1.7 \mathrm{kPa} \mathrm{O}\right.$, balance $\left.\mathrm{He}\right)$

Figure 10. Rate constant ratio, $\mathrm{k}_{3} / \mathrm{k}_{1}$, as a function of vanadia surface density on $\mathrm{VO}_{\mathrm{x}} / \mathrm{Al}_{2} \mathrm{O}_{3}$ catalysts: (a) ethane reactant (14 $\mathrm{kPa} \mathrm{C}_{2} \mathrm{H}_{6}, 1.7 \mathrm{kPa} \mathrm{O}_{2}$, balance $\left.\mathrm{He}\right)$, (b) propane reactant $\left(14 \mathrm{kPa} \mathrm{C}_{3} \mathrm{H}_{8}, 1.7 \mathrm{kPa} \mathrm{O}_{2}\right.$, balance $\mathrm{He}$ )

Figure 11. Difference between $\mathrm{ODH}$ activation energy and alkene combustion activation energy $\left(\Delta \mathrm{E}_{13}=\mathrm{E}_{1}-\mathrm{E}_{3}\right)$ on $\mathrm{VO}_{\mathrm{x}} / \mathrm{Al}_{2} \mathrm{O}_{3}$ catalysts: (a) ethane $\left(663 \mathrm{~K}, 14 \mathrm{kPa} \mathrm{C}_{2} \mathrm{H}_{6}, 1.7 \mathrm{kPa}\right.$ $\mathrm{O}_{2}$, balance $\left.\mathrm{He}\right),\left(\right.$ b) propane $\left(663 \mathrm{~K}, 14 \mathrm{kPa} \mathrm{C}_{3} \mathrm{H}_{8}, 1.7 \mathrm{kPa} \mathrm{O}\right.$, balance $\left.\mathrm{He}\right)$ 


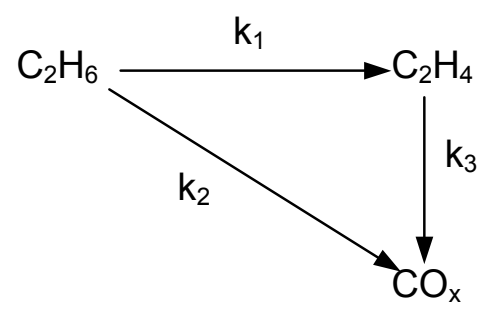

$$
\begin{aligned}
& \mathrm{r}_{1}=\mathrm{k}_{1}{ }^{\prime}\left[\mathrm{C}_{2} \mathrm{H}_{6}\right]\left[\mathrm{O}_{2}\right]^{\mathrm{n}}=\mathrm{k}_{1}\left[\mathrm{C}_{2} \mathrm{H}_{6}\right] \\
& \mathrm{r}_{2}=\mathrm{k}_{2}\left[\mathrm{C}_{2} \mathrm{H}_{6}\right]\left[\mathrm{O}_{2}\right]^{\mathrm{m}}=\mathrm{k}_{2}\left[\mathrm{C}_{2} \mathrm{H}_{6}\right] \\
& \mathrm{r}_{3}=\mathrm{k}_{3}\left[\mathrm{C}_{2} \mathrm{H}_{4}\right]\left[\mathrm{O}_{2}\right]^{\prime}=\mathrm{k}_{3}\left[\mathrm{C}_{2} \mathrm{H}_{4}\right]
\end{aligned}
$$

Scheme 1 


\section{TABLE 1}

Surface Area and V Surface Density for $\mathrm{VO}_{\mathrm{x}} / \mathrm{Al}_{2} \mathrm{O}_{3}$ Catalysts

\begin{tabular}{cccc}
\hline $\begin{array}{c}\mathrm{V}_{2} \mathrm{O}_{5} \text { loading } \\
(\mathrm{wt} \%)\end{array}$ & $\begin{array}{c}\text { Surface area } \\
\left(\mathrm{m}^{2} / \mathrm{g}\right)\end{array}$ & $\begin{array}{c}\text { Nominal } \mathrm{VO}_{\mathrm{x}} \text { surface } \\
\text { density }\left({\left.\mathrm{V} / \mathrm{nm}^{2}\right)}^{2}\right.\end{array}$ & $\begin{array}{c}\text { Surface area } \\
\text { normalized by amount } \\
\text { of support }\left(\mathrm{m}^{2} / \mathrm{g} \mathrm{Al}_{2} \mathrm{O}_{3}\right)\end{array}$ \\
\hline 0 & 99 & 0 & 99 \\
2 & 95 & 1.4 & 97 \\
5 & 93 & 3.6 & 97 \\
10 & 83 & 8.0 & 94 \\
15 & 80 & 12.5 & 91 \\
20 & 73 & 16.6 & 83 \\
30 & 58 & 34.2 & \\
\hline
\end{tabular}




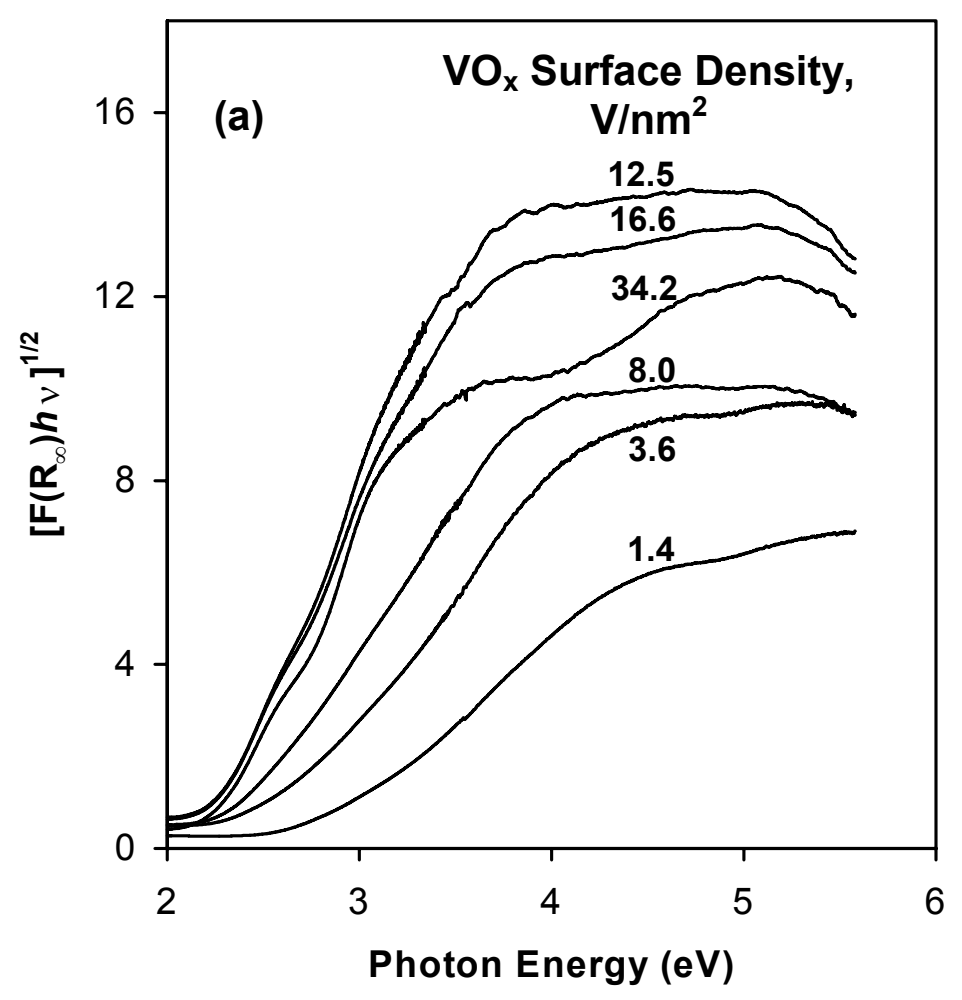

Figure 1a 


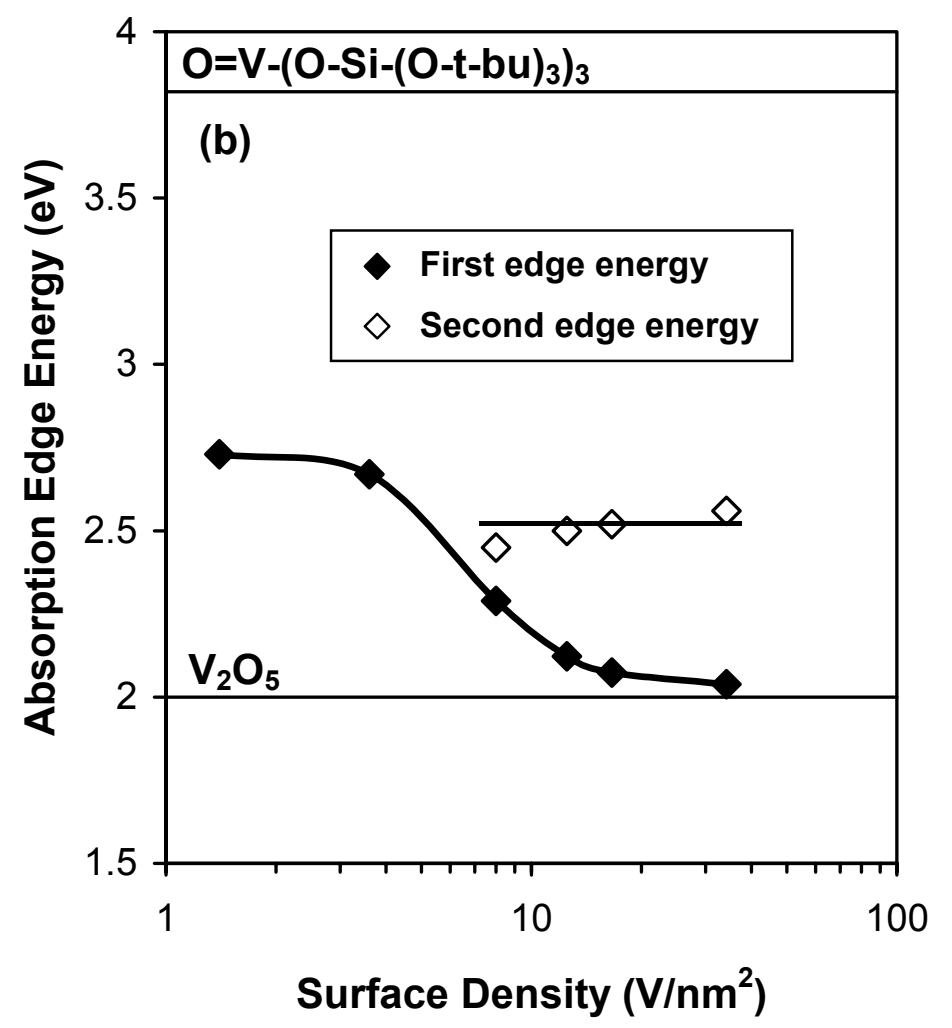

Figure 1b 


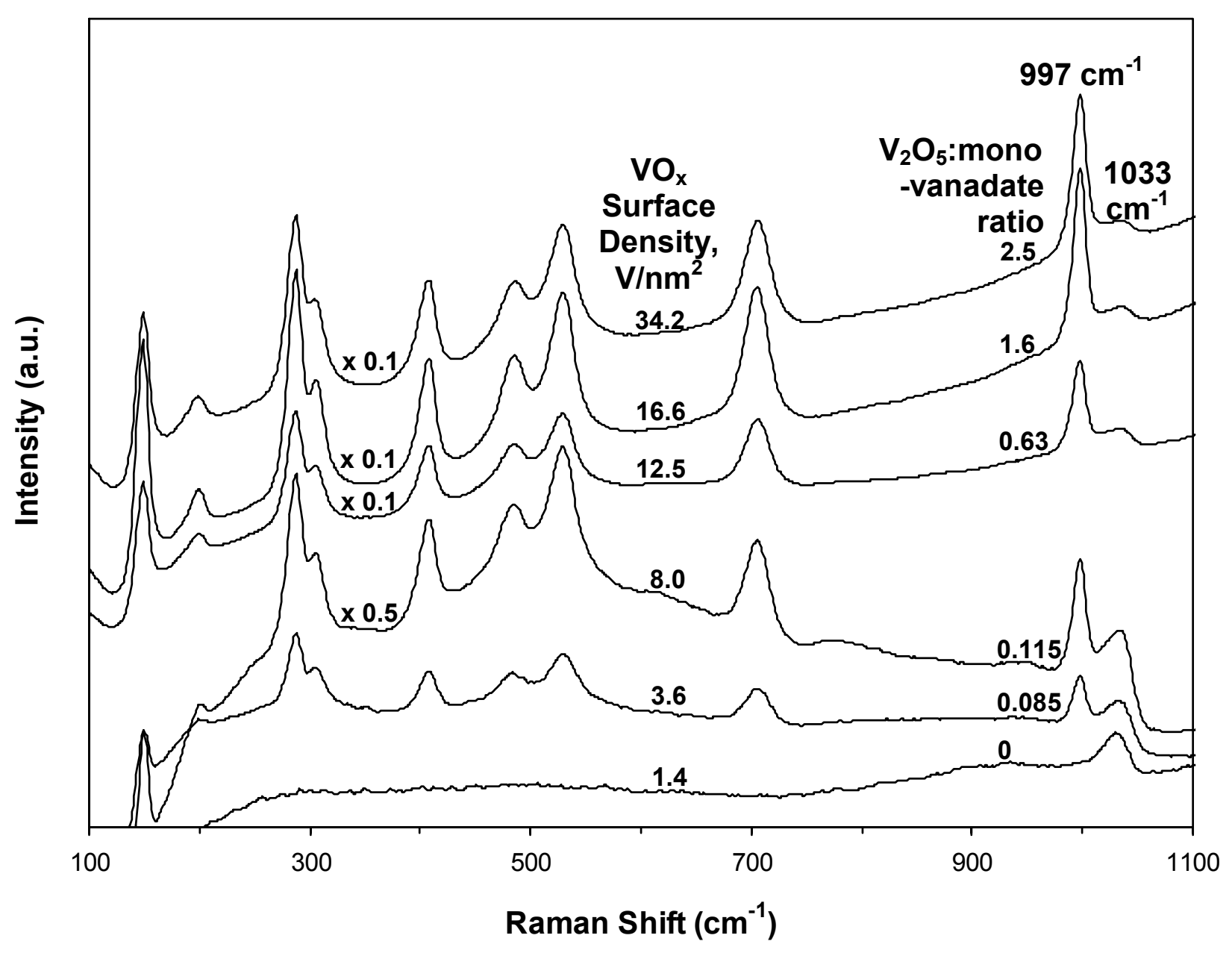

Figure 2 


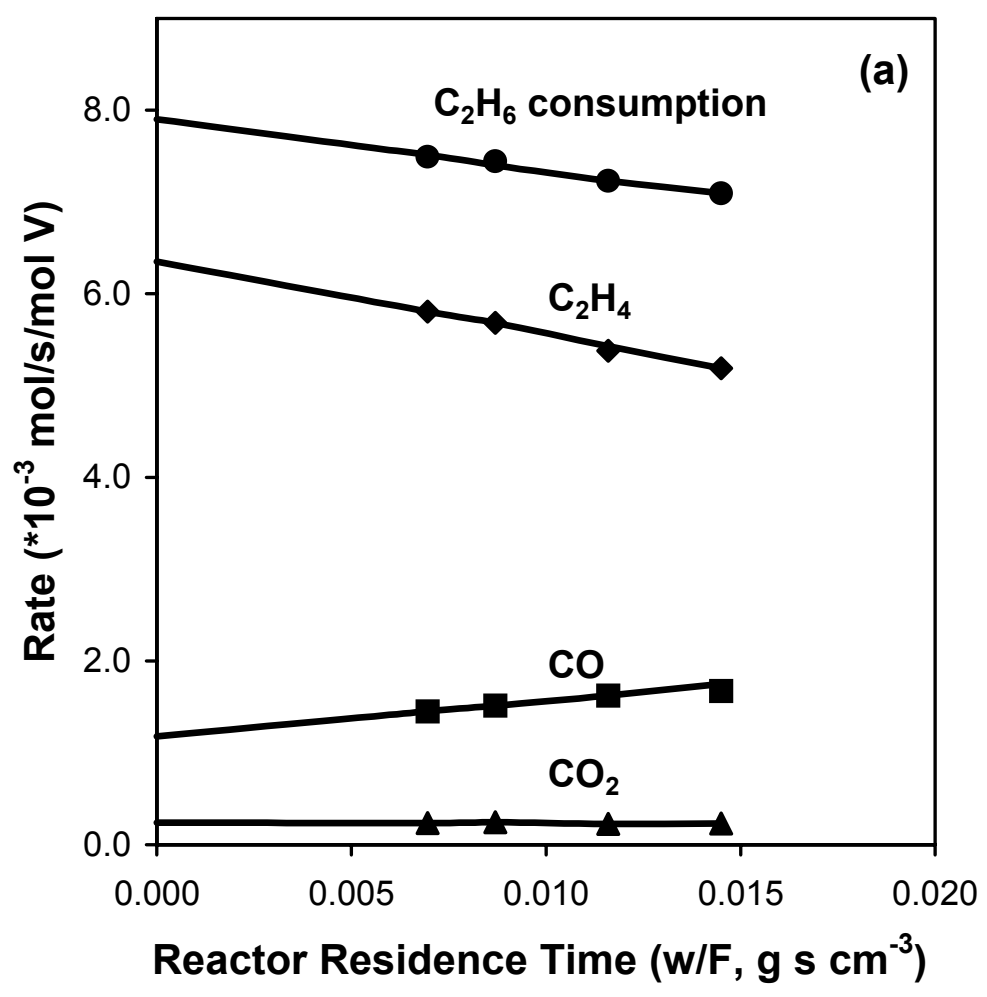

Figure $3 \mathrm{a}$ 


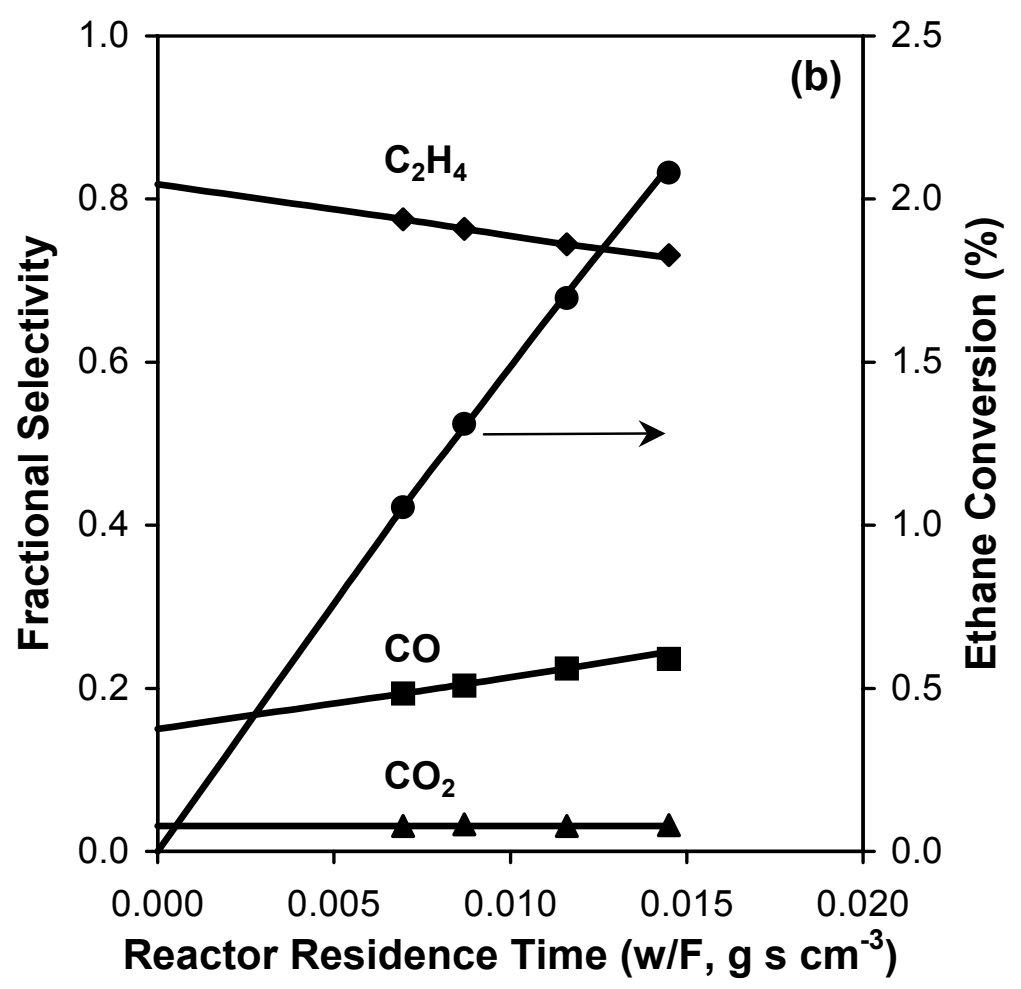

Figure $3 b$ 


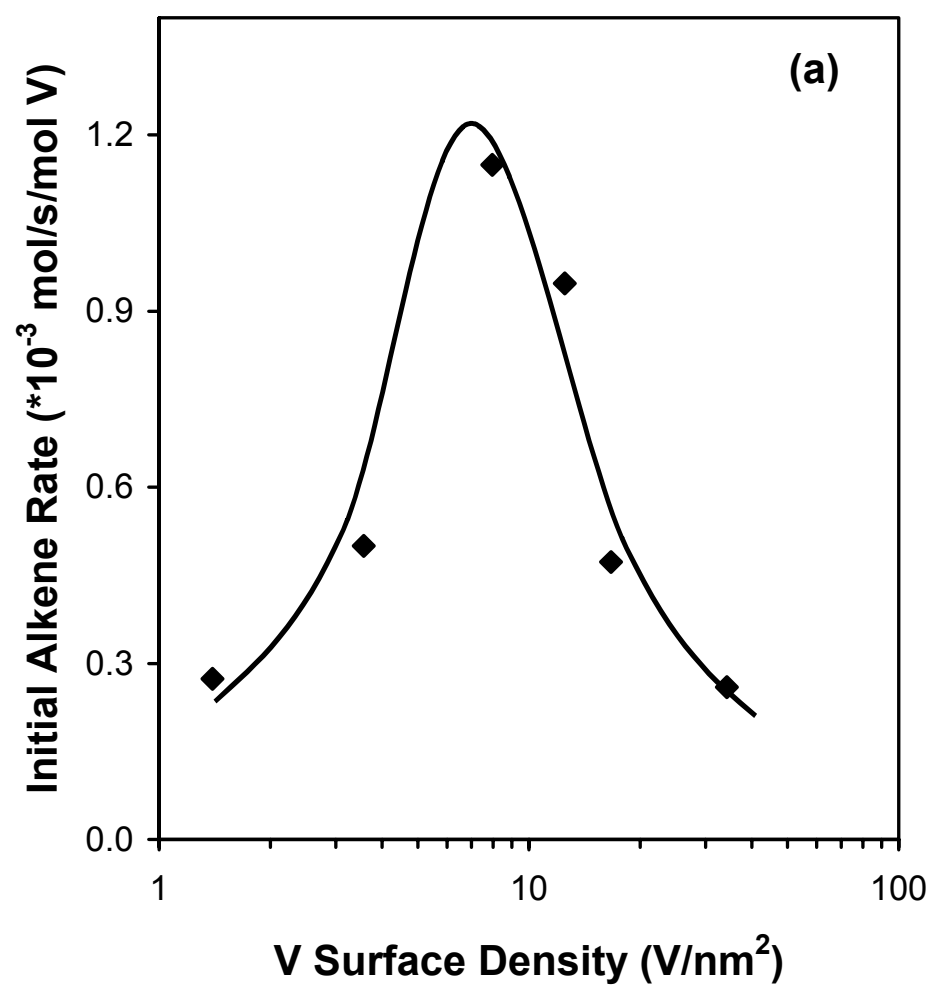

Figure 4a 


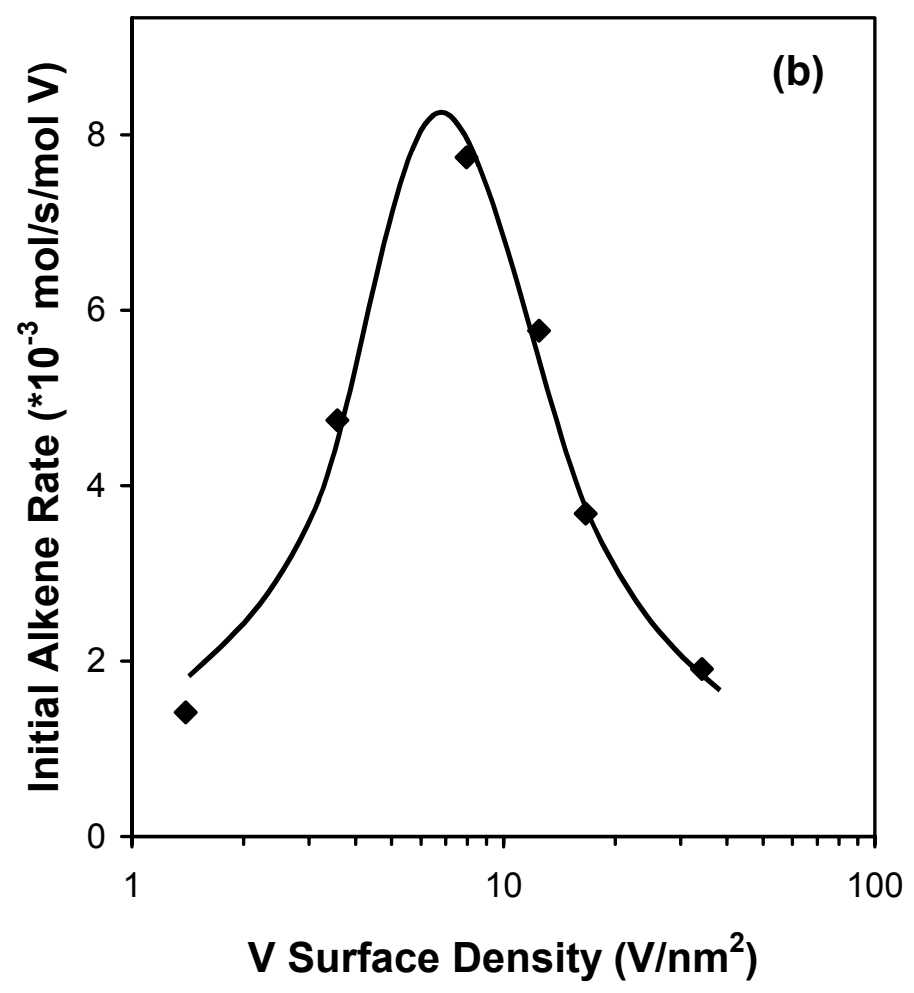

Figure $4 b$ 


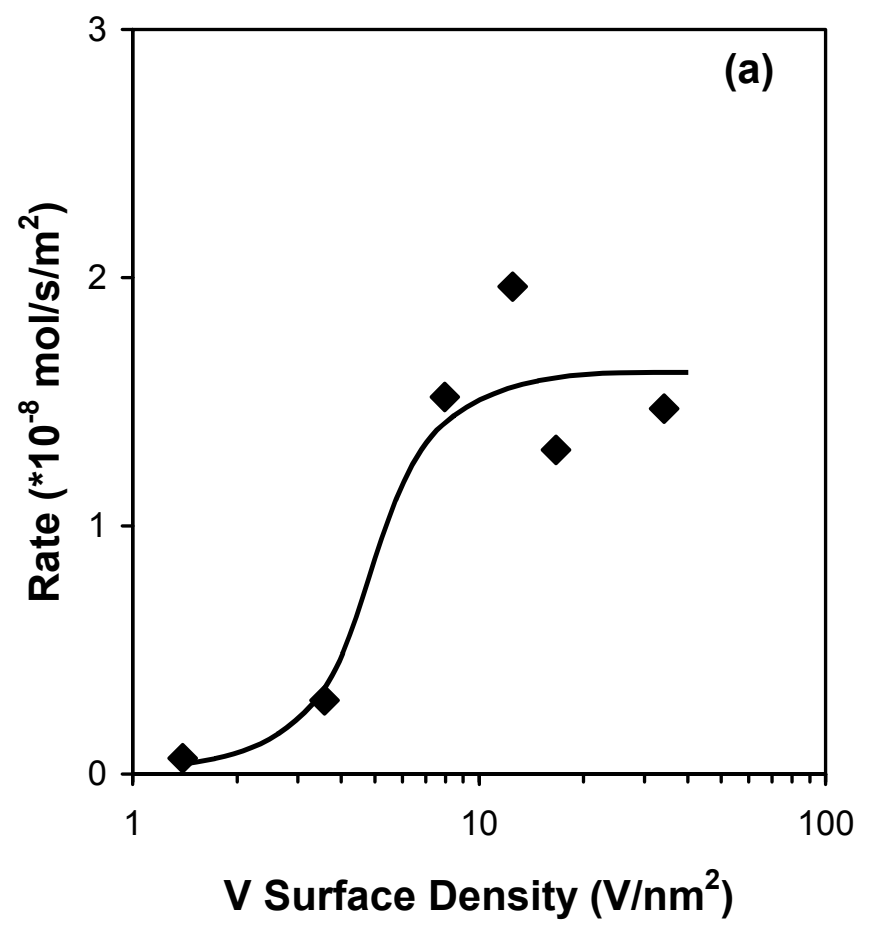

Figure 5a 


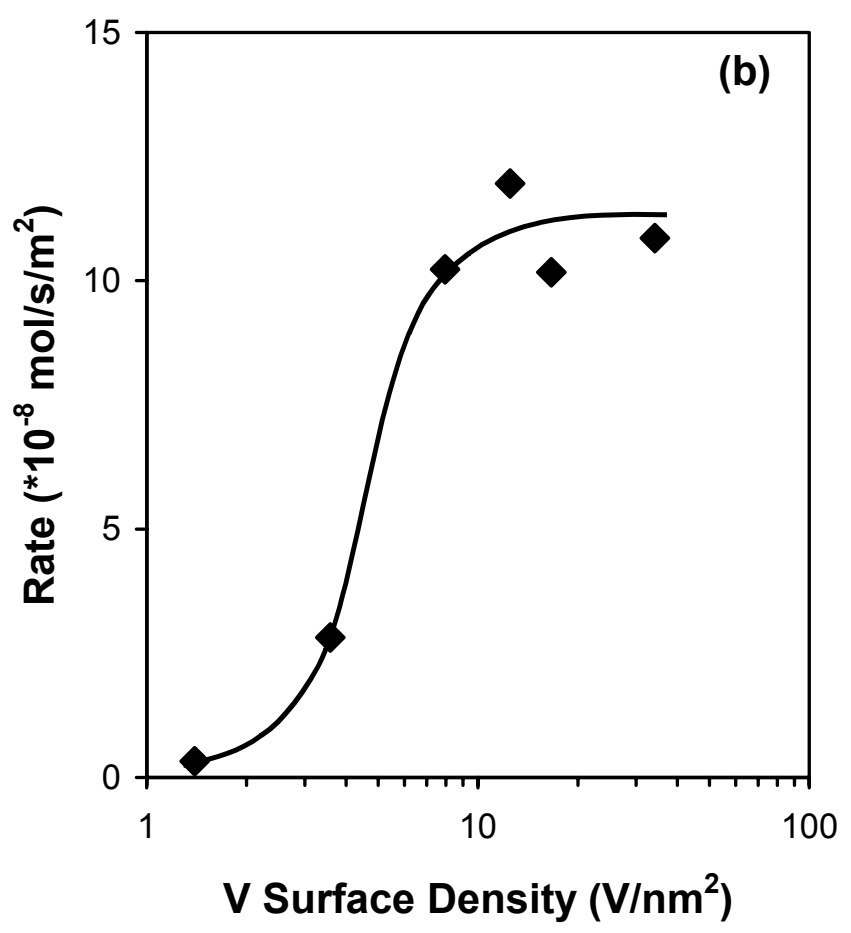

Figure $5 b$ 


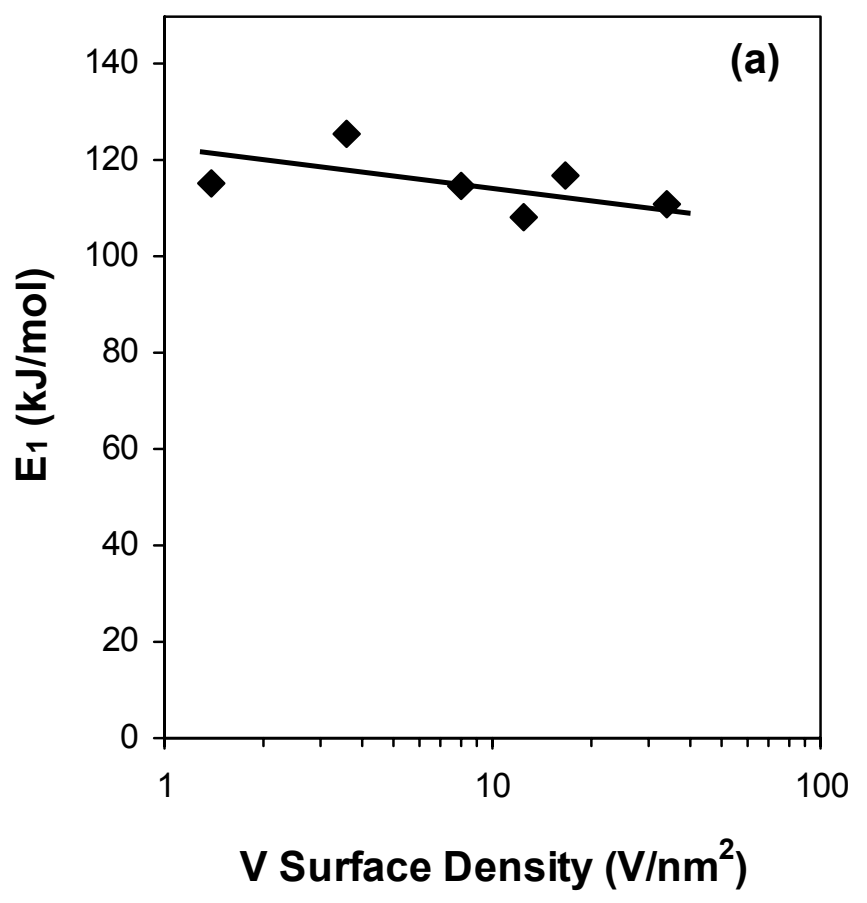

Figure 6a 


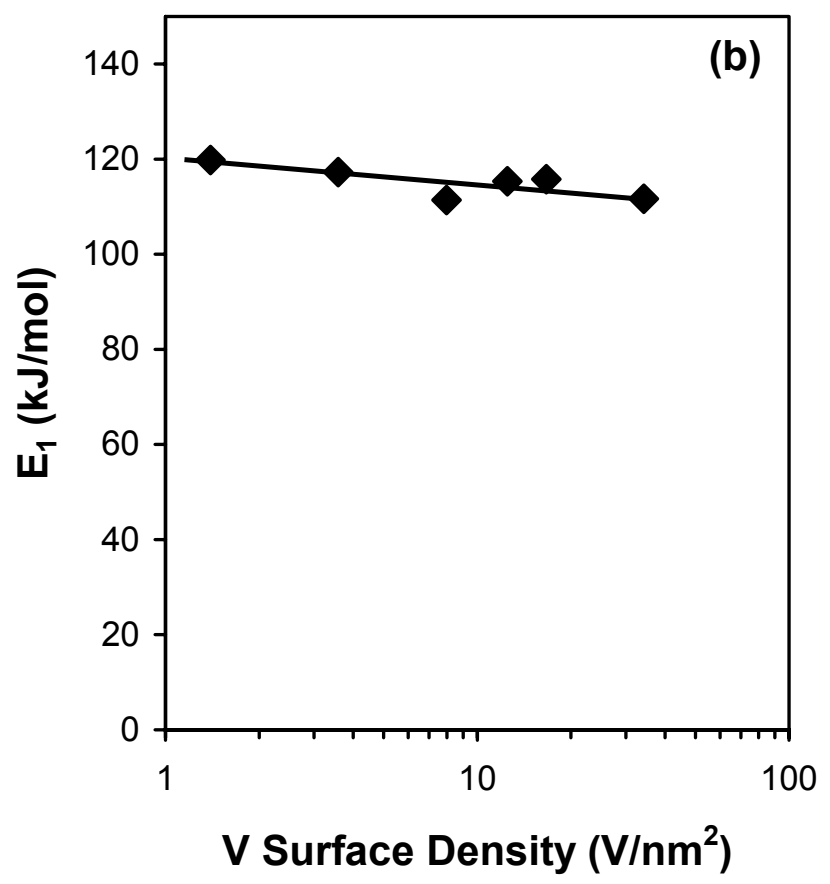

Figure $6 b$ 


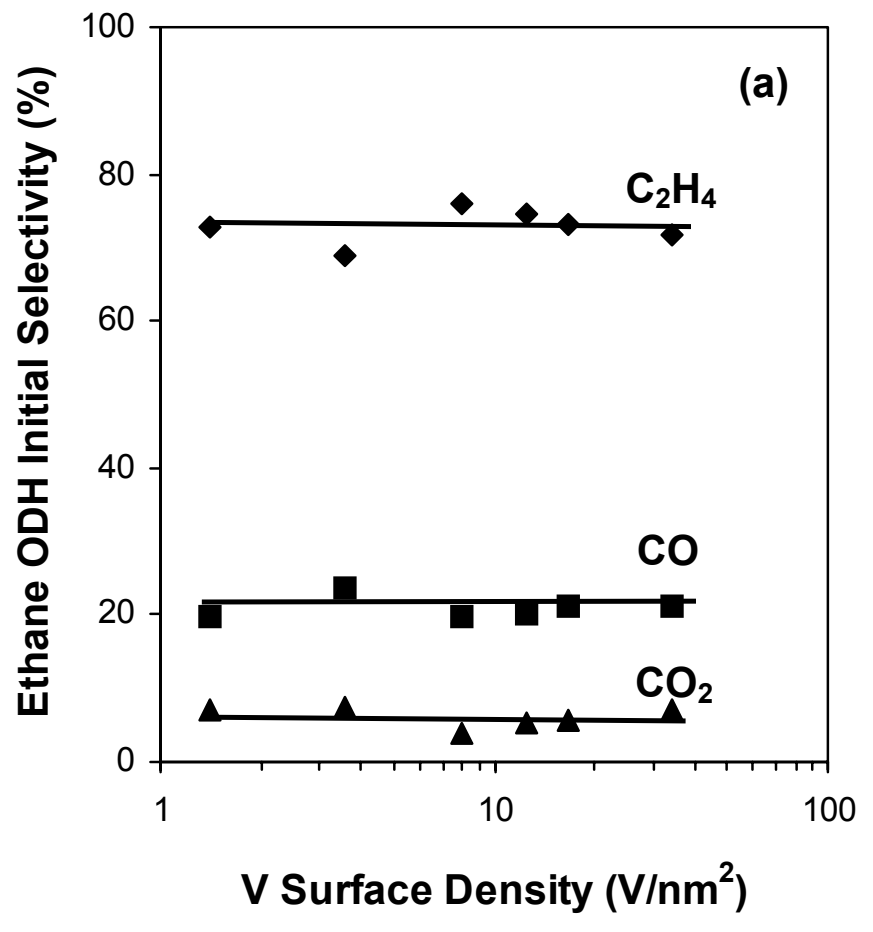

Figure 7a 


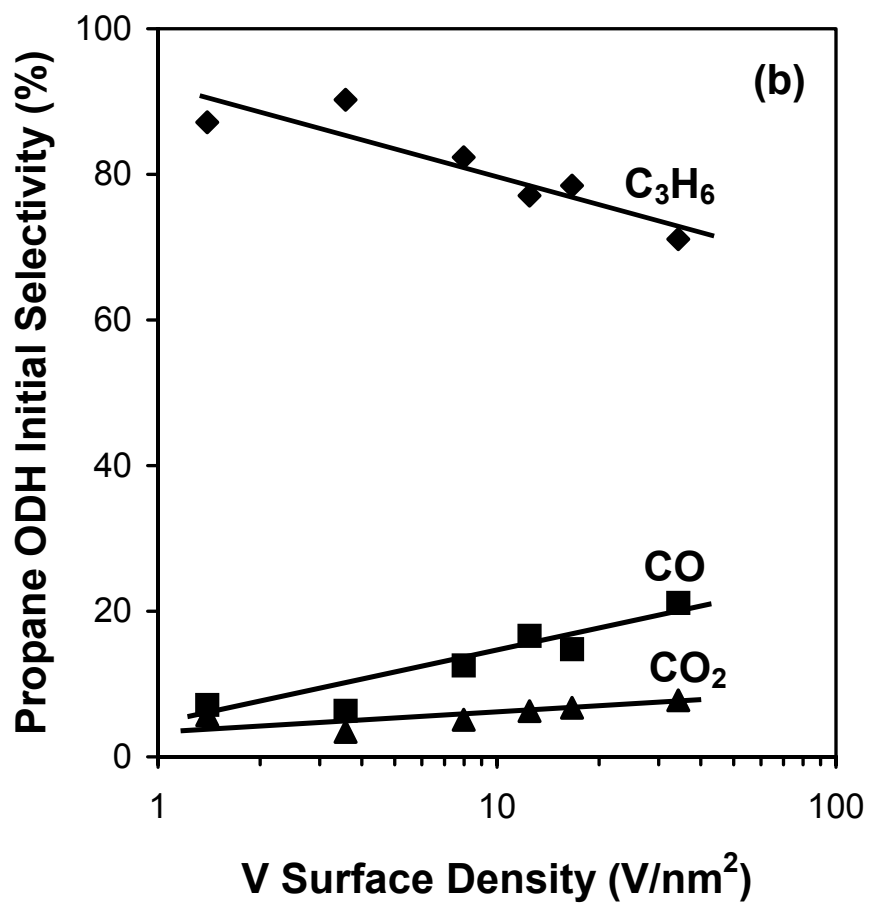

Figure $7 b$ 


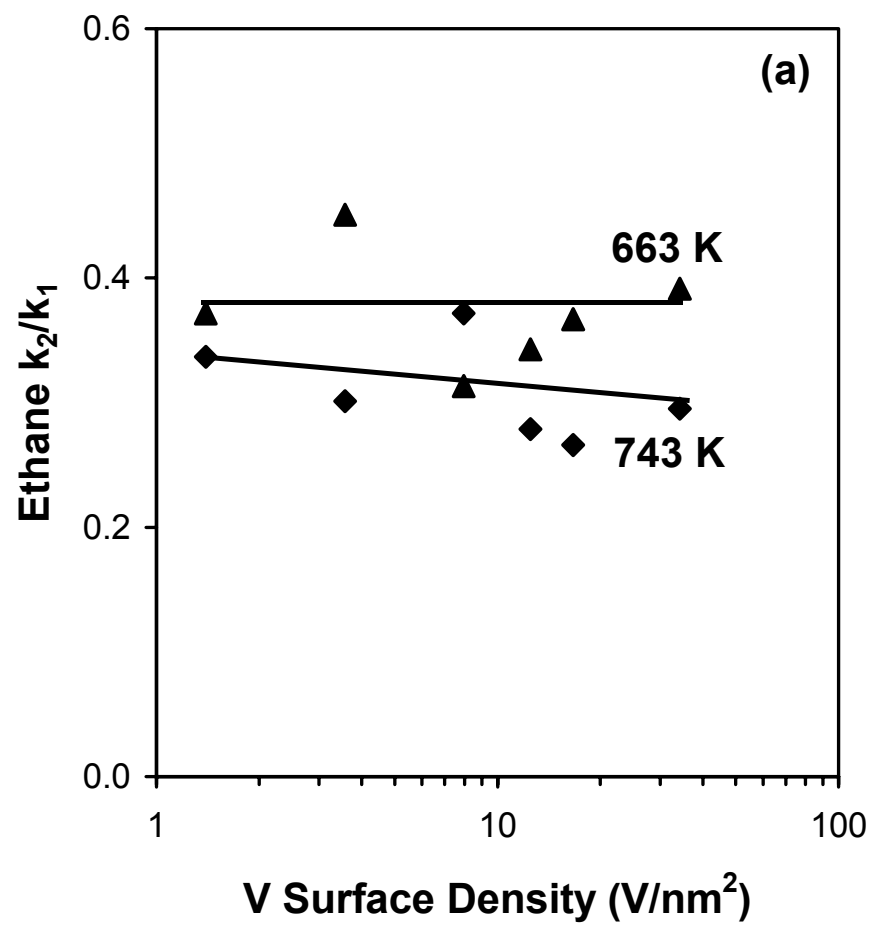

Figure 8a 


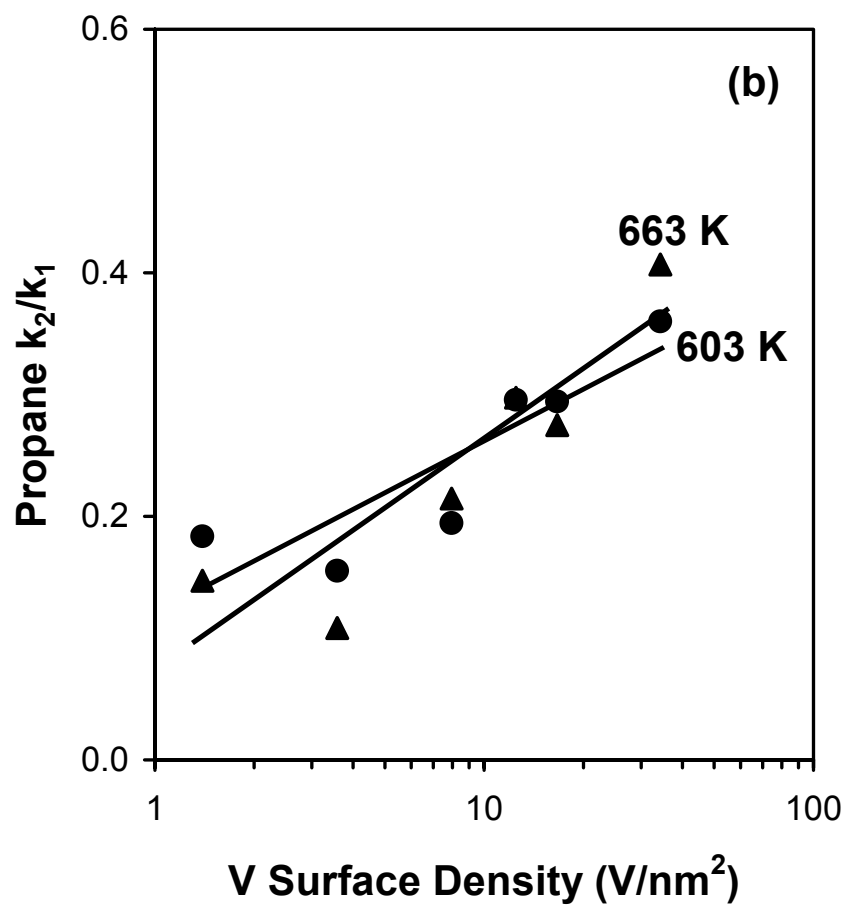

Figure $8 b$ 


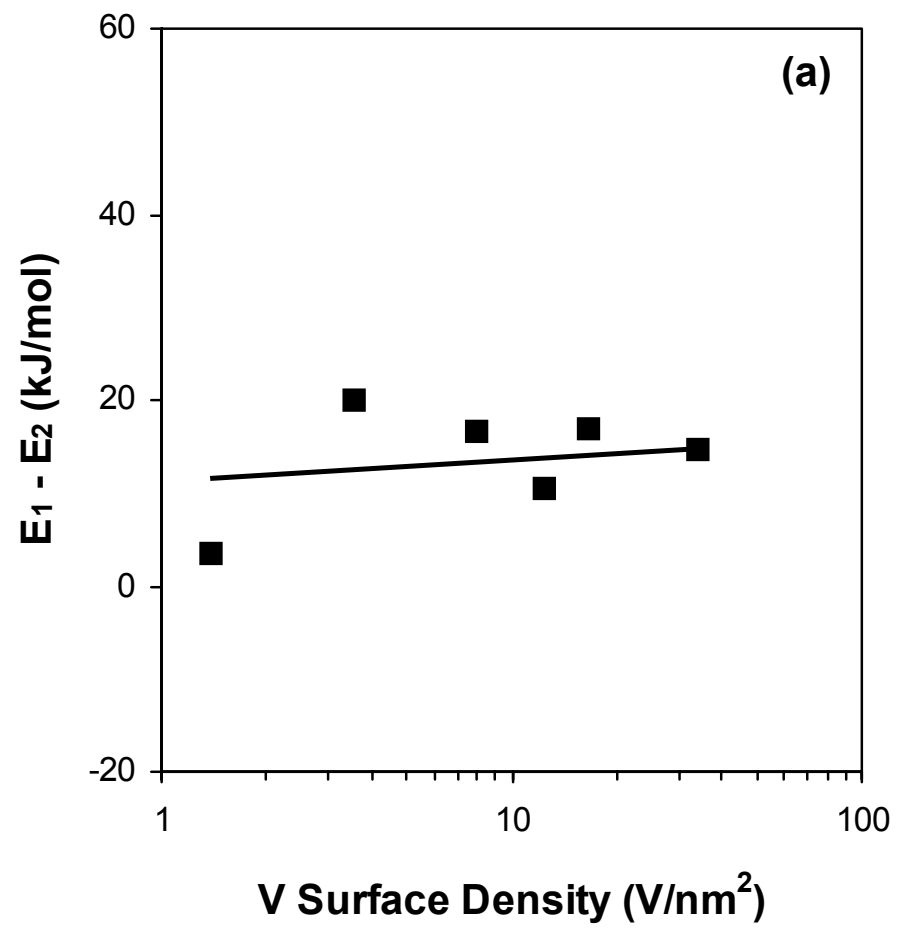

Figure 9a 


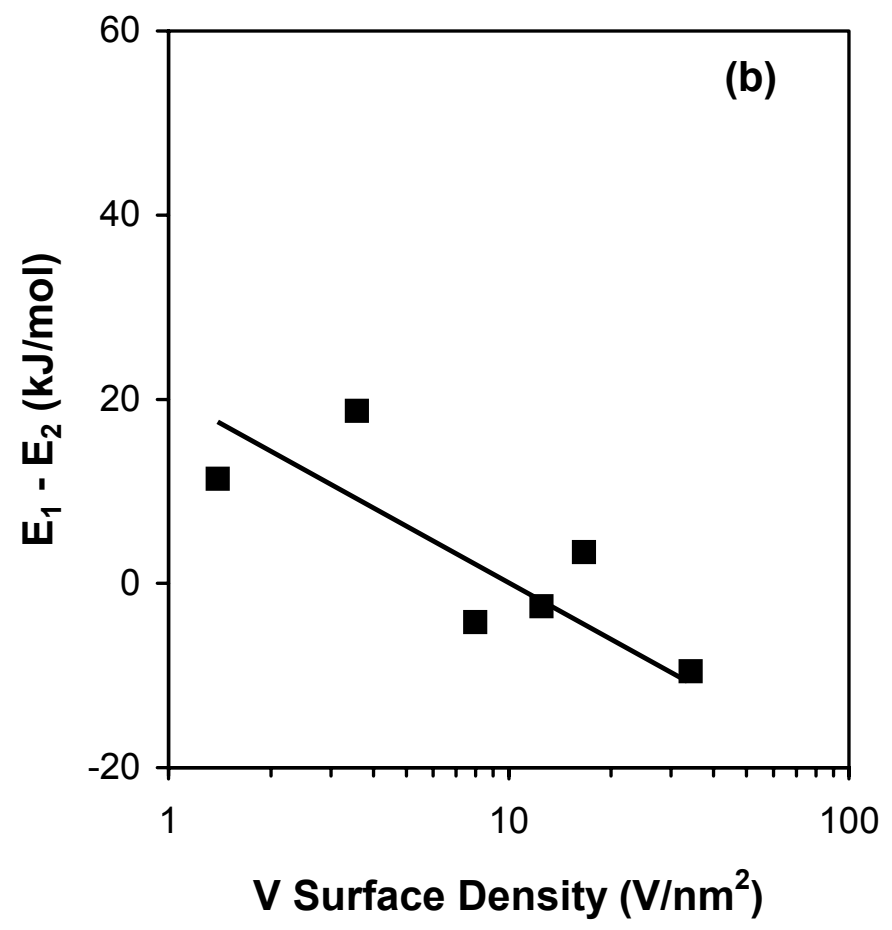

Figure 9b 


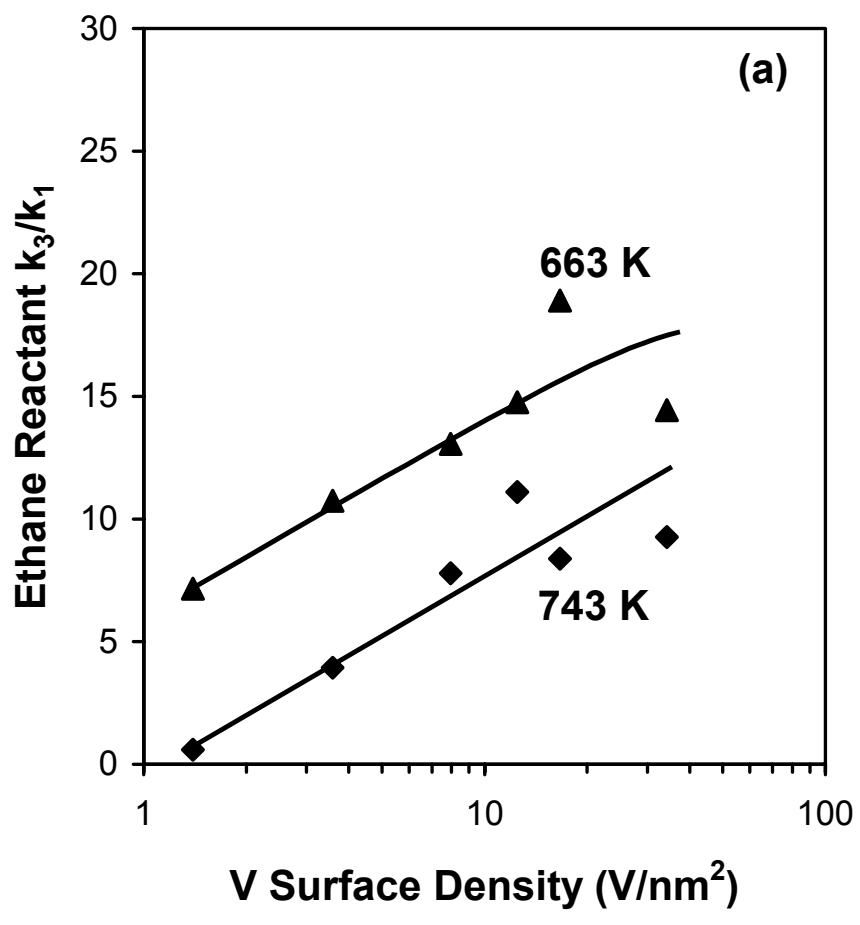

Figure 10a 


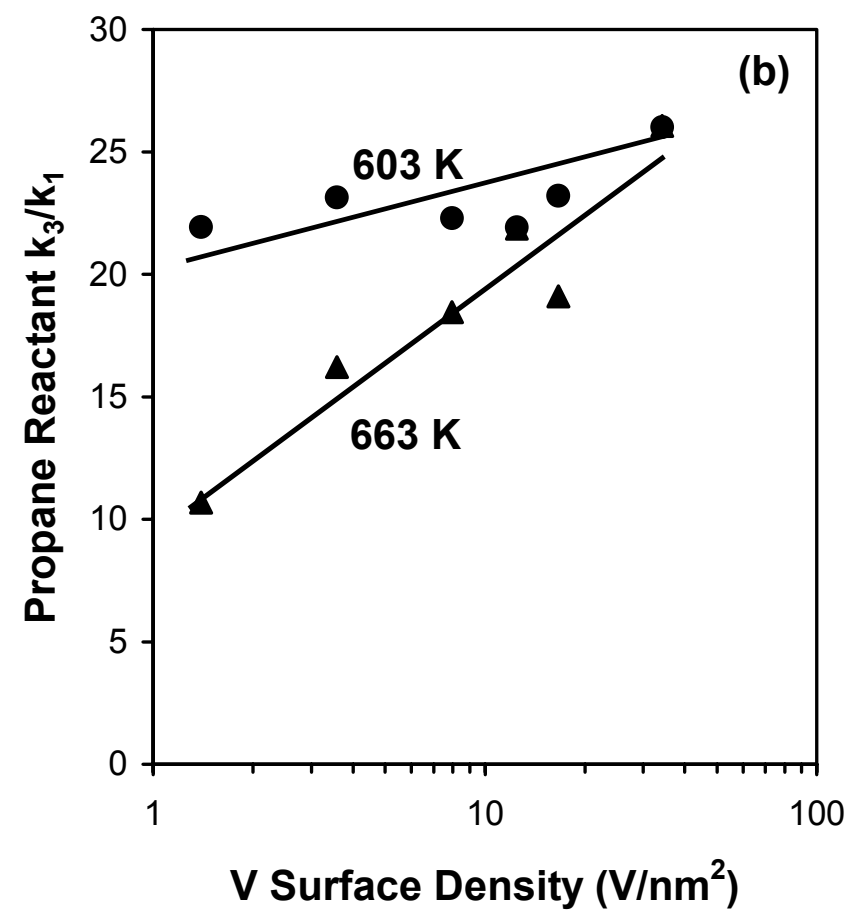

Figure $10 \mathrm{~b}$ 


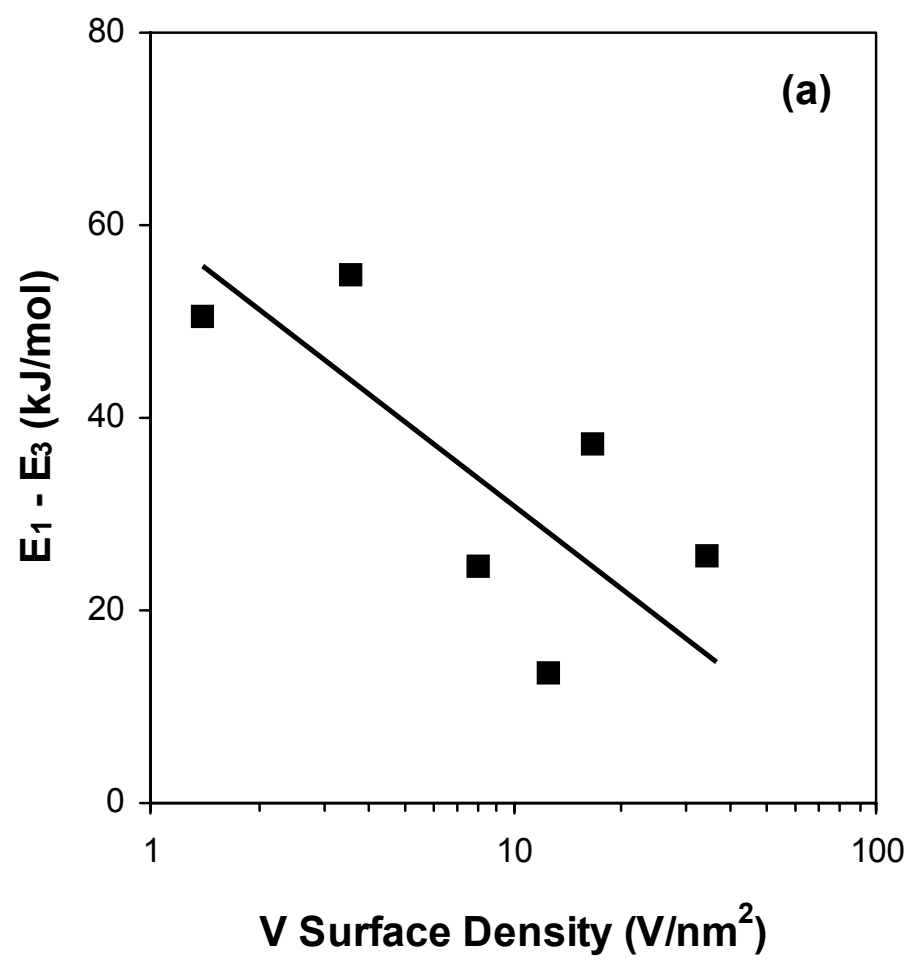

Figure 11a 


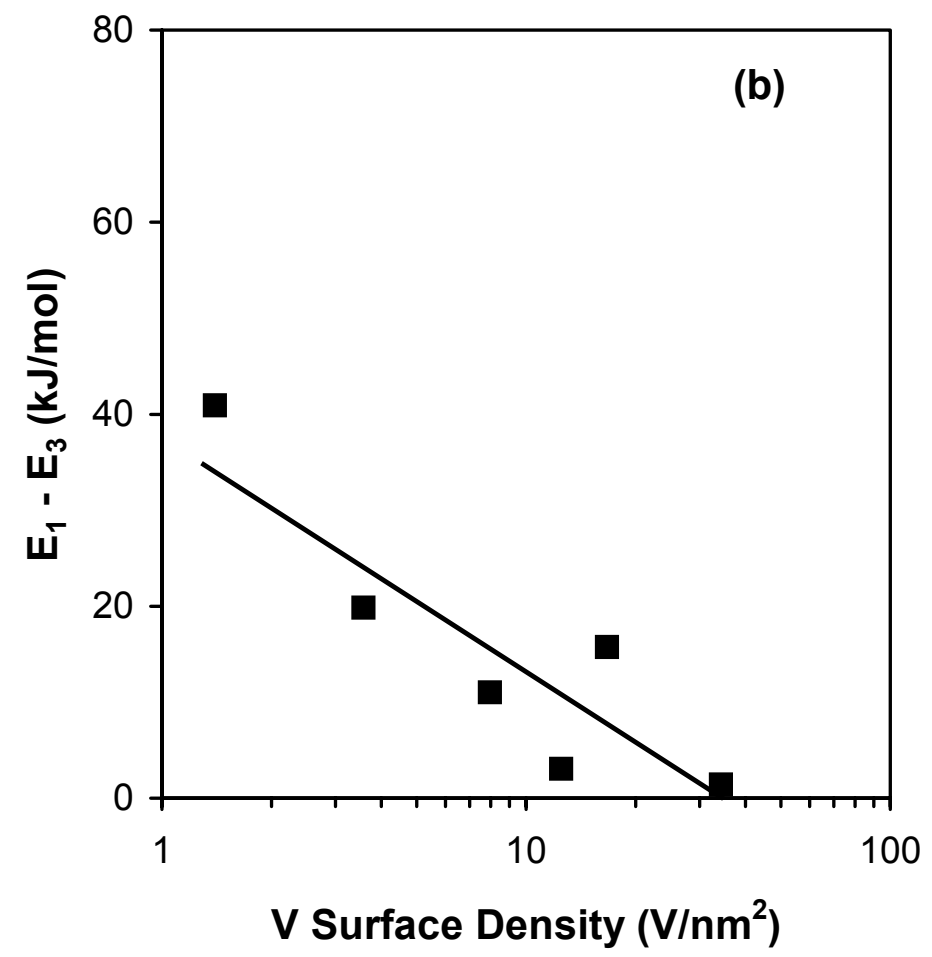

Figure $11 b$ 